\title{
A conceptual model of the species composition of the original riparian rainforest of the Clarence River Floodplain, New South Wales
}

\author{
Peter Rose
}

School of Environment, Science and Engineering, Southern Cross University, Lismore, Australia pjrose @ westnet.com.au

\begin{abstract}
The riparian rainforest on the streamside levees of the coastal floodplain of the Clarence River on the North Coast of New South Wales was cleared during the 1860s by small landholders seeking fertile land. Only three small remnants remain. Using a combination of historical species lists, corner trees from surveyors' portion plans, habitat information and the NSW Scientific Committee's (1999) determination for lowland rainforest on floodplain a conceptual model of the original distribution of rainforest suballiances on the levees of the Clarence River coastal floodplain is proposed.
\end{abstract}

Cunninghamia (2014) 14: 153-178

doi:10.7751/cunninghamia.2014.14.008

\section{Introduction}

Before European settlement the banks of the coastal floodplain of the Clarence River in northern New South Wales (lat. $29.5^{\circ} \mathrm{S}$, long. $153.2^{\circ} \mathrm{E}$ ) (Figure 1) were vegetated by a band of rainforest that was known colloquially as 'brush' (Hodgkinson 1845, Rose 2012). In 1839, The Deputy Surveyor-General, Captain Perry onboard one of the first vessels to enter the Clarence River noted that:

owing to the denseness of the brush on the banks, no part of the country could be seen from the deck of the vessel, but was completely screened by a mass of most luxuriant vegetation: the stems of gigantic trees, covered with climbing plants of various descriptions, and which fell down in graceful festoons from the upper branches, produced an effect observable only in a region fresh from the hand of nature (Lang 1847 p. 40)

J D Lang was seeking land for Scottish immigrants and Commissioner Fry reported to him that on the lower 20 miles $(32 \mathrm{~km})$ that:

the immediate borders of the stream being covered with a dense impervious brush (Lang 1847 p.52) and that for the next 30 miles $(48 \mathrm{~km})$ the land:

becomes more elevated, more open, and of infinitely better description ....., a belt of brush varying in width from one to four hundred yards (91-366m) fringing the stream all the way up (Lang 1847 p. 52)

The first Europeans to move into the Clarence Valley were cedar getters and graziers who mainly left the riparian rainforest undisturbed. The cedar getters only selectively removed the valuable red cedar from the rainforest; most of the easy to cut cedar exhausted by 1842 (Vader 1987 p.94). The impenetrable rainforest was of no use to the grazier (Lang 1847, Stubbs 1996 p. 124) but changes to the land laws (The Order in Council of 1847 followed by the Crown Lands Alienation Act 1861) enabled farmers to obtain smaller blocks (Stubbs 1996). The 'brush' forest blocks along the banks of the Clarence River were sought after due to their fertile soil. Due to its luxuriant nature the 'brush' was not possible to burn and it could only be cleared by cutting down the large trees with an axe. This was hard work and would take a week to clear an acre $\left(4,000 \mathrm{~m}^{2}\right)$. Virtually none of the timber was sold, but merely allowed to dry for about a year and then burnt. In the meantime the settlers planted maize in between 


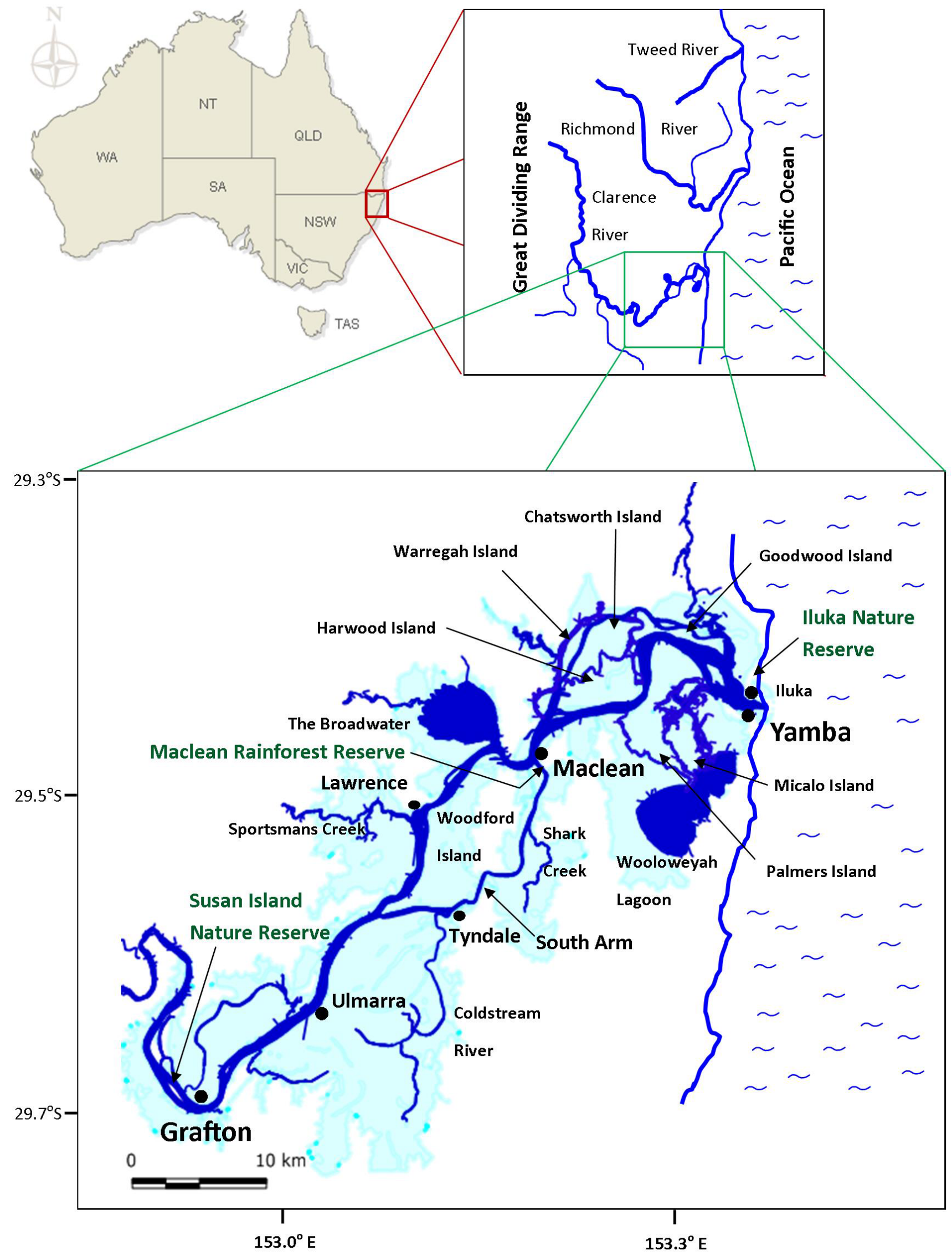

Figure 1. Map showing the location of the Clarence River floodplain (light blue), streams, islands, towns and remnant rainforest reserves. 
the logs (McFarlane 1924). In this way the rainforest was rapidly cleared from the banks of the Clarence.

Charles Moore, Director of the Sydney Botanical Gardens visited the area in 1861 and found that:

Even the banks of the Clarence, which some six or eight years ago presented on both sides one continuous mass of this description of forest, varying in breadth from one hundred yards to almost half-a-mile has been already cleared for many miles - the fate which will soon overtake all the brush country available for cultivation, unless the government cause reserves to be made for the preservation of at least some portion of a class of trees which are both interesting and beautiful, even if not otherwise valuable (Moore 1861a).

By 1868 a reporter of the Sydney Morning Herald (16 December 1868 p. 5) found that:

The scrubs have wholly disappeared from the banks of the river and where once the vine clad trees rose up, wreathed with thick robes of foliage and tinted with bright flowers, there are now groups of farm buildings, lines of fencing, patches of garden, and green fields of waving corn.

Another reporter (Sydney Morning Herald, 10 August 1871 p. 2) noted that near the mouth:

The thick brushes which once grew here have been cut down on most of the islands, and given place to cultivation.

In his next article (Sydney Morning Herald, 14 August 1871 p. 2) he observes that:

The tourist may form some idea of the Clarence as it was when first discovered, in 1832, from the vegetation which still grows in rank luxuriance on some of the smaller islands - emerald gems in the glittering stream.

implying that the rest of the brushes (or riparian rainforest) had been totally cleared by that time.

The purpose of this paper is to present the available information of the now largely destroyed riparian rainforest in a manner that could be of use for anyone wishing to reestablish parts of this rainforest. For example Clarence Valley Council has an Environmental Trust grant for Clarence Estuary Riparian and Wetland Restoration and is actively engaged in riparian weed control, native plant establishment and livestock exclusion fencing. Clarence
Landcare has a project for the collection of local native seed species and growing the plants/trees for specific projects (Wilson 2014a). A workshop of the Clarence Floodplain and Estuary Partnership agreed that riparian rehabilitation to be a priority activity for the partners (Wilson 2014b). This paper may help these agencies in their riparian restoration work to seek out species that were originally there and not only those that are currently in the riparian zone.

The starting point for this investigation was the NSW Scientific Committee's (1999) Determination for lowland rainforest on floodplain as an Endangered Ecological Community for the New South Wales North Coast Bioregion. This determination uses Floyd's (1990) classification for rainforests. Floyd (1990, v.2 microfiche) recorded the species found in the three remaining rainforest remnants (Susan Island Nature Reserve, Maclean Rainforest Reserve and Iluka Nature Reserve, Figure 1) on or near the Clarence floodplain. Historical surveyors' corner tree data and species lists from botanists, who visited the area prior to the clearing of the riparian rainforest, was another source for rainforest species found on the floodplain. Rich (1996) suggested that littoral rainforest may extend further inland along estuarine river systems, and as suballiance No. 16 is the main suballiance at the Iluka littoral rainforest reserve, this suballiance was also included in all of the assessments.

The available habitat and historical information was used to determine if any of the eleven suballiances in the Determination (NSW Scientific Committee 1999) could be excluded from being present on the Clarence floodplain and enabled the generation of a conceptual model of the distribution of rainforest suballiances across the riparian levees on the Clarence floodplain.

\section{Methods}

Floyd (1990) used floristics or habitat characteristics to differentiate between rainforest suballiances with key characteristics based on soil type, location, altitude, rainfall etc. or a combination of habitat characteristics. Table 1 gives a simple scale created to subjectively assess the habitat of the Clarence floodplain to the habitat characteristics of the eleven suballiances (Floyd 1990) from the NSW Scientific Committees (1999) determination.

Table 1. Criteria used in assessing the habitat fit of Floyd's suballiances to the riparian rainforest on the Clarence floodplain.

\section{Assessment criteria}

Good fit - the habitat criterial for the suballiances aligns with the habitat of the floodplain - the main suballiances

Niches - the habitat criterial for the suballiances aligns with small areas on the floodplain - present throughout in small areas.

Edges - the habitat criteria for the suballiances does not align with the main area of the floodplain, but it does for adjoining areas - transitional

No fit - the habitat criterial for the suballiances do not fit with the floodplain or its adjoining areas.
Habitat fit category 
Table 2. Numerical ratings applied to Floyd's (1990 v. 1 p. 23) abundance ratings
Abundance rating
VC Very common
C Common
O Occasional
R Rare

\author{
Basis for abundance rating \\ Top 1-6 most common species \\ More than 5 individuals \\ 2 to about 5 individuals \\ 1 only seen
}

Numerical rating
10
6
3
1

Table 3 Worked example of the process of plotting abundance Vs number of species. The value for Ficus macrophylla for Suballiance 1 is generated from it being present in two of four sites (data not shown) with abundance values of 3 (Occasional) and 6 (Common) to give a rounded down abundance value of 2.2 (sum of 9 divided by $4=2.25$ ). This process was repeated for all the other suballiances of interest and also for another four species. The highlighted values are those that are plotted in Figure 2.

\begin{tabular}{|c|c|c|c|c|c|c|c|c|c|c|c|c|}
\hline Species & 1 & 2 & 3 & 4 & 5 & 6 & 16 & 23 & 24 & 25 & 26 & 33 \\
\hline Ficus macrophylla & 2.2 & 5.0 & 8.4 & 1.0 & 0.7 & & & 2.6 & 1.4 & & & 0.2 \\
\hline Dendrocnide excelsa & 3.8 & 5.0 & 6.0 & 1.3 & 1.8 & & & 3.0 & 2.0 & & & 1.6 \\
\hline Streblus brunonianus & 1.0 & 5.0 & 5.6 & & 1.5 & & & 9.2 & 3.3 & 8.7 & 0.2 & 0.2 \\
\hline Malotus philippensis & 1.5 & 1.5 & 4.4 & 2.0 & 1.5 & & & 6.0 & 4.0 & 5.3 & & 0.6 \\
\hline Cryptocarya obovata & 1.0 & 6.0 & 4.0 & 1.7 & 2.8 & 1.0 & & 0.6 & 2.3 & 4.0 & 0.8 & 1.4 \\
\hline Sum of average abundance values & 9.5 & 22.5 & 28.4 & 6.0 & 8.3 & 1.0 & & 21.4 & 13.0 & 18.0 & 1.0 & 4.0 \\
\hline Total abundance value & 225 & 196 & 193 & 160 & 156 & 86 & 193 & 214 & 132 & 126 & 107 & 213 \\
\hline $\begin{array}{l}\text { Percentage of example list of the total } \\
\text { abundance }\end{array}$ & $4.2 \%$ & $11.5 \%$ & $14.7 \%$ & $3.8 \%$ & $5.3 \%$ & $1.2 \%$ & $0.0 \%$ & $10.0 \%$ & $9.8 \%$ & $14.3 \%$ & $0.9 \%$ & $1.9 \%$ \\
\hline No. of species (max. 5) & 5 & 5 & 5 & 4 & 5 & 1 & 0 & 5 & 5 & 3 & 2 & 5 \\
\hline Total No. of species & 161 & 93 & 146 & 103 & 134 & 99 & 95 & 166 & 75 & 52 & 80 & 184 \\
\hline Percentage of example list of the total & $3.1 \%$ & $5.4 \%$ & $3.4 \%$ & $3.9 \%$ & $3.7 \%$ & $1.0 \%$ & $0.0 \%$ & $3.0 \%$ & $6.7 \%$ & $5.8 \%$ & $2.5 \%$ & $2.7 \%$ \\
\hline
\end{tabular}

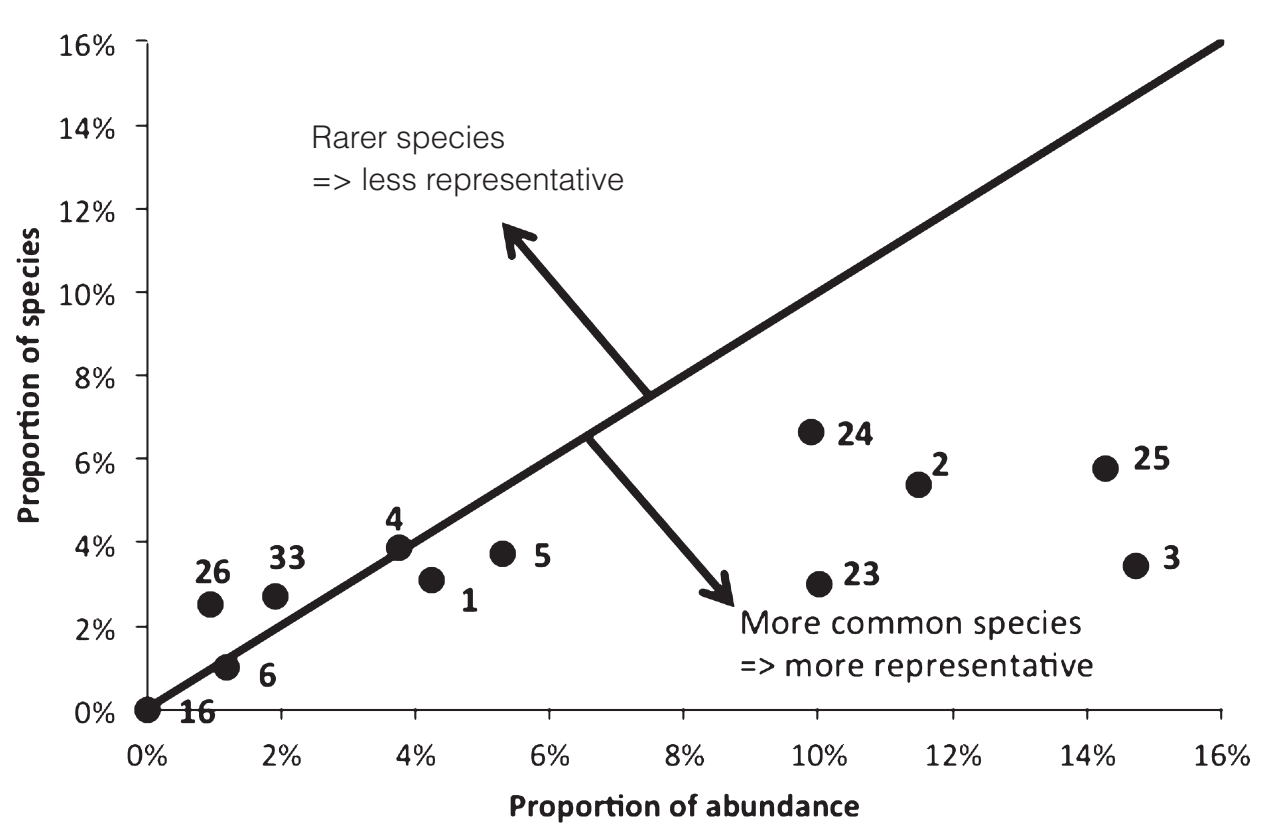

Figure 2 Worked example of plotting abundance Vs number of species. The graph has separated the suballiances into two groups. In the more representative group, only four of the seven suballiances where all five species were represented made it into this group. In suballiance 25 , only 3 species were present, but due to them being very common, this suballiance has also made it into the more representative group. Using the proportion of numbers and abundance provides an extra dimension in trying to complete this historical jigsaw puzzle. Suballiances that are above the line will tend to be less representative, as the species that are present are less common. In contrast, those suballiances that are very abundant will tend to be placed below the dividing line, as their higher abundance values will push them to the right on the graph. 
A species list was created from the original surveyors' corner tree data and species lists from botanists who visited the region prior to the clearing of the rainforest and will be referred to as the historical species list (Appendix 1).

The historical species list was compared to the species list in each of Floyd's (1990) suballiances to extract the number of species represented, and to generate an abundance rating. Floyd (1990) has provided a species list for each of his suballiances with an associated abundance rating from 2-5 representative sites. This abundance rating was converted to numerical values to reflect the relative weighting of the original rating (Table 2 ). It is a simple progressive scale with the interval between groups increasing by one and it aims to provide weight to the important species without completely ignoring the others. A linear scale $(1,2,3,4)$ was used initially but it was considered that it did not put enough emphasis on the very common species and too much emphasis on rare species.

The abundance values for each species were averaged to give an average abundance for that species in that suballiance. The average abundance values were then summed for the historical species that were present in each of the suballiances. The proportion of the sum of the abundance values for the historical species to the total of the abundance value for each suballiance was plotted against the proportion of the number of species from the historical list to the total number of species in the suballiance. This process is explained in a simplified example (Table 3, Figure 2).

\section{Results}

Two botanists' visited the region prior to the complete loss of the riparian rainforest, Charles Moore and William Carron.

Charles Moore (1861a, b, 1867), Director of the Sydney Botanic Gardens, collected many rainforest specimens on his visit to the Clarence in 1861, with 28 named in two separate newspaper articles. It is also recorded that he published A catalogue of Northern Timbers, which he later revised several times (King 1974). The Botanic Gardens Library (part of the National Herbarium of New South Wales) was not able to locate a copy of this Catalogue, but had a copy of his catalogue of Woods indigenous to the Northern district of the colony from the London International Exhibition, 1862. This catalogue had 116 timber specimens from the Clarence and Richmond districts, with 75 of these from the Clarence, some without species names.

William Carron (1872a, b), a collector for the Sydney Botanic Gardens was sent to the Northern Rivers to seek out possible sites for timber reserves. Only one rainforest timber reserve, located 6-7 miles $(10-11 \mathrm{~km})$ north of Grafton, with 20 tree species was nominated.

A list of 77 species (the historical species list, Appendix 1) was compiled from botanists' data combined with the surveyors' corner tree data. Though the corner tree data was only recorded as common names, it was possible to suggest a scientific name with the aid of a list of 78 species from the adjacent Richmond River region

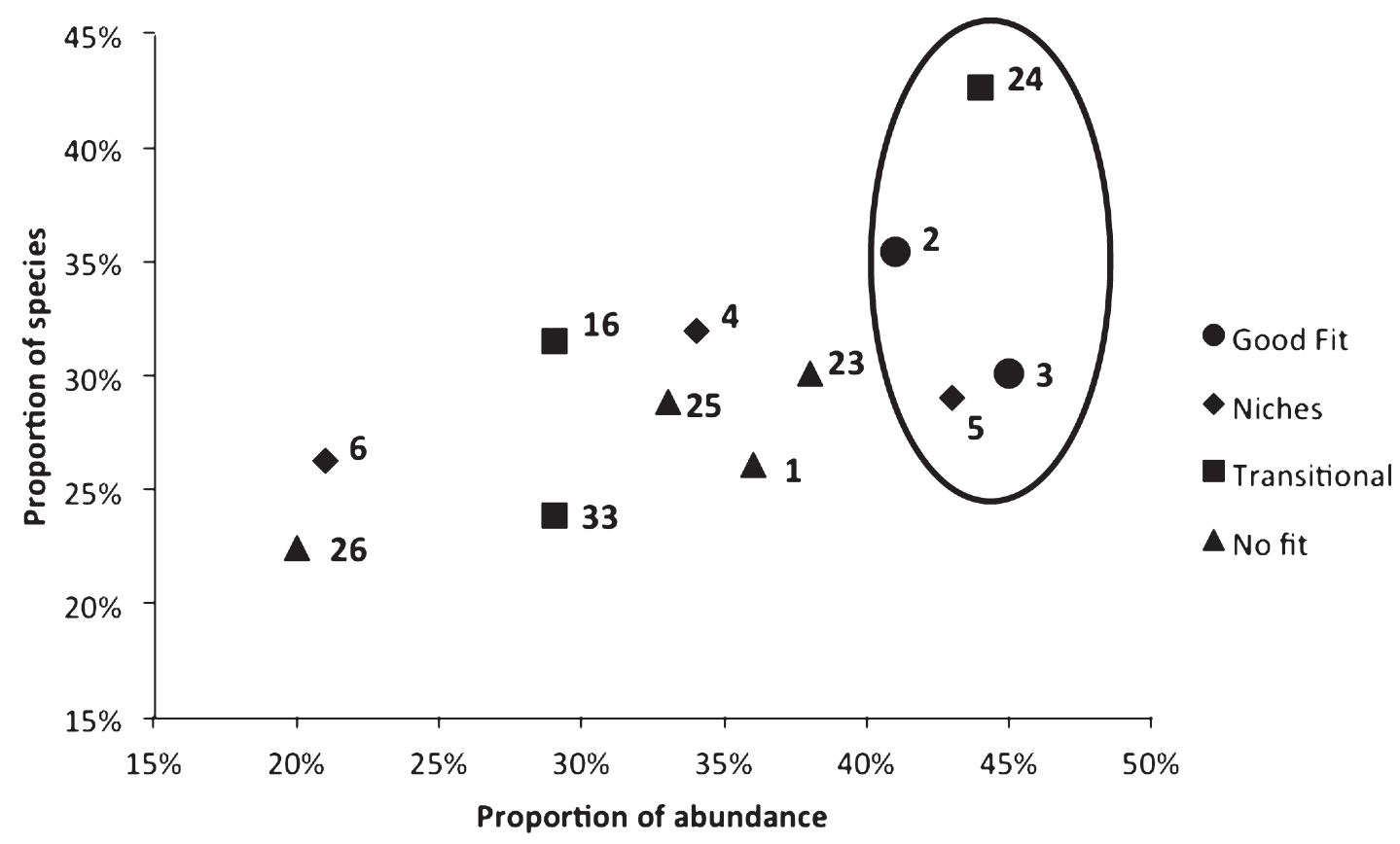

Figure 3. The proportion of species from the historical list in each of Floyd's (1990) suballiances (Table 4 for names) plotted against the proportion of the average abundance of that species in the suballiance with the subjective habitat rating displayed as various point shapes. The suballiances within the circle are those more likely to have been present on the Clarence floodplain. 
Table 3. Possible explanations as to why these species were not represented in the 12 suballiances of interest.

\author{
No. of Reason \\ species \\ Only the genus was nominated \\ Callerya megasperma - A vine - only tree data has been captured in this project. \\ Doubles - two species names eventually converged to one species. \\ These may be incorrectly named:
}

Acacia trinervata: Restricted to western Sydney and adjacent lower Blue Mountains (Flora of Australia v. 11B 2001 p. 45) and therefore may be incorrectly named.

Epicarpurus orientalis: The common name of Elm and the description suggest the name Aphananthe philippinensis may be more correct.

Owenia venosa: The common name of Tulipwood and the description suggest the name Harpullia pendula may be more correct.

These species were not listed in the $\mathbf{1 2}$ suballiances of interest due to incorrect habitat:

Acacia binervata: In more or less abundance all along the coast; a handsome, small sized tree. Timber hard, and occasionally used for carpenters' tools. MALLA WAUNDIE. Clarence and Richmond brush forests (Moore 1861b).

Denhamia pittosporoides: In dry rainforest and vine thicket on basaltic or basaltically enriched soil (Floyd 2008). A tree of moderate size; timber not used. Clarence brush forests (Moore 1861b).

Erythrina vespertilio: Dry and semi-dry rainforests and also in adjoining open forest country (Floyd 2008). On open forest land bordering on the thick brush forests (Moore 1861b).

Geijera salicifolia: In dry rainforest on steep dry stony slopes and sides of gorges. On skeletal soils derived from slates (Floyd 2008). Brush forests, generally in the Northern districts (Moore 1861b).

This species may have been totally lost to NSW:

Cupaniopsis serrata: Not recorded with certainty in NSW. (Floyd 2008). A very ornamental tree of small size, plentiful in the brushes. Timber not used. GULWIN GULWIN. Richmond and Clarence (Moore 1861b).

Unknowns - The following species were unable to be located in the Australian Plant Name Index:

Nephelium lanuginosum: Sapindaceae. A fine tree, attaining a height of 80 feet and 3 feet in diameter. Timber occasionally used for building purposes. UROOBIE. Clarence and Richmond brush forests, plentiful (Moore 1861b).

Nephelium lucidum: Julip wood. This tree is very generally known wherever it grows, both on account of the beauty of its heart wood, and its excellence for firewood; for this latter purpose it is preferred about Grafton, where it is abundant, to almost any other. The tree grows to a large size, but it is seldom that the stem is solid, being generally decayed near the heart. The wood is exceedingly strong, and richly coloured with different shades, from black to yellow, will take a high polish, and in a good specimen is very beautiful. This has been occasionally employed in Sydney for cabinet work, but it does not appear to have received that attention that it deserves. (Moore 1861a, p.3)

(Clarence and Richmond Examiner and New England Advertiser, 1 April, 1873, Appendix 5). The likely current scientific and common names were determined using the Australian Plant Name Index (www.cpbr.gov. au/apni/) cross referenced with Floyd (2008). Of the 77 species in the complete list 60 were represented in the 12 suballiances that were deemed to be of interest (Appendix 2 ). An attempt has been made to ascertain why the other 17 species were not represented (Table 3 ).

The 12 suballiances were subjectively assessed for habitat fit (Table 4). The proportion of the sum of the average abundance values (Appendix 3) for each suballiance was plotted against the proportion of the number of species in each suballiance (Figure 3). In addition, the habitat fit rating of each suballiance was noted on the graph by different shape points. The resulting graph provided some insight on the fit of the 12 suballiances to the Clarence floodplain (Figure 3).

\section{Discussion}

The main criteria used to determine the possible distribution of Floyd's rainforest suballiances across the Clarence floodplain was a subjective assessment of the fit of the habitat characteristics of each suballiance to the habitat of the Clarence floodplain. To provide supporting evidence a methodology has been created that utilises a historical species list in a "what if" scenario. If the historical species list had been collected in a particular suballiance, then a particular proportion of the number of species and their abundance would have resulted. These values would vary for each suballiance along both axes, providing an extra dimension of the fit of each suballiance to the Clarence floodplain. There are many reasons why this methodology is not particularly robust, however, in much the same way that a palaeontologist will suggest how an animal may look, from a few bones, it is an attempt to use the available historical data to provide some insight into species distribution in rainforests that were cut down in the 1860s (Stubbs 1996, Rose 2012). 
Table 4. Habitat descriptions of the suballiances nominated by the New South Wales Scientific Committee as being associated with the community lowland rainforest of New South Wales North Coast bioregion. In addition, the littoral suballiance No. 16 has been included. These have been ranked for habitat fit (Table 1) to the Clarence floodplain with qualifying remarks.

Lowland alluvium. Well drained sites on the fertile alluvial flats, which were initially logged and now farmed. May suffer from seasonal moisture stress.

Good fit for the Clarence floodplain as it has a low rainfall period during spring.

Cryptocarya obovata - Dendrocnide excels - Ficus spp - Araucaria

Floodplain alluvium. The major sub-alliance on the well-drained, fertile, basaltically-enriched alluvial lowland floodplains north from the Manning River, the majority now under agriculture.

Good fit for the Clarence.

Streambank alluvium. Exists as a lowland riverine fringing community within a more extensive community eg No 5, 6 or 33. The stream bank location is due to the large fruit (up to $30 \mathrm{~mm}$ diameter), which is dispersed by water and not by birds in New South Wales.

This could have been a niche community along the banks of the Clarence.

Moist, alluvial flats and benches. A reliable soil moisture level appears to be a major requirement. Often derived from weathering of lowland plateaux.

This suballiance can occur where hills merge with the floodplain without a backswamp in between e.g. at Maclean, Woodford Island, Ashby and Tyndale.

\section{Archontophoenix - Livistona}

Excess soil moisture. Also known as palm forests. Drainage is impeded and there is free surface water during the wet season. Soil type is not critical.

No palm forests are indicated on the portion plans, only 'tall ferns'. However, it could be a transition community to the backswamps in some locations. river.

Ficus spp - Streblus - Dendrocnide - Cassine

Central and South coasts on krasnozem at moderate low altitude. To the south of the Bellinger Valley. It occupies dry rocky slopes, ravines and headlands on fertile but often shallow soils. It does not occupy a streamside niche.

Wrong location and soil type.

Gallery rainforest along streams on basaltic alluvium in minimal rainfall areas (950-1100mm). Mainly in the upper Clarence and Richmond valleys. A drier phase of the suballiance No. 5.

The annual rainfall on the floodplain is too high for this suballiance to be a major component of the floodplain. However, it fits with the upper end of the floodplain around Grafton as a transition to the main suballiances.

Streambank basaltic alluvium with high rainfall. Richmond River.

Wrong location.

Southern Extension of No. 24 on less fertile alluvium.

Wrong location.

Warm temperate/subtropical rainforest on alluvium or enriched yellow earth. Sloanea above $650 \mathrm{~m}$ altitude. A transition suballiance between the subtropical and warm temperate rainforests often in gullies.

The floodplain environment on the Clarence of levees transitioning to backplains does not seem to fit this suballiance. Some small areas may be present as per the comments for No 5, in gullies that merge onto alluvial terraces. 
Assessing habitat characteristics of the eleven rainforest suballiances nominated by the New South Wales Scientific Committee as possibly being present prior to European settlement on the Clarence floodplain, enabled four to be eliminated. Of the remaining suballiances it is suggested that three were present in niche environments, two plus a littoral rainforest suballiance occupied transitional environments and two were the main suballiances. The habitat ranking process for the suballiances was supported to some extent by the abundance and species number data generated from Floyd's (1990, v.2 microfiche) species lists when cross referenced with the historical species list (Appendix 1, Figure 3).

Suballiance No. 23 rated almost as high as the suballiances suggested for the Clarence floodplain (Figure 3), even though it is only present on the NSW Central and South Coasts. This could be due to either of two reasons: Option 1) Floyd (1990, v.1 p. 36) noted that in prior times that the region to the north of the Clarence was drier and seemed to be a major barrier to the north-south movement of some rainforest species. The concept of a species barrier was supported by Rich (1996) who grouped 33 littoral rainforest remnants from all of NSW into 3 groups using PATN analysis. The Iluka littoral rainforest near the mouth of the Clarence River was the northern most representative of the southern group, providing additional evidence of the Clarence as a boundary for some rainforest species. If the rainforest species on the floodplain followed the trend of the littoral rainforest species by having a stronger affinity with the southern rainforest groups, this could explain why the southern suballiance No. 23 rated so highly in Figure 3. Option 2) The second reason could be that those who contributed to the historical species list may have been more familiar with the rainforest species closer to home (Sydney), and so they were more familiar with the species from suballiance No. 23. The contrary argument to this option is the position of suballiance No. 23 in Figure 3, where it lies more to the right on the graph indicating that it is fairly well represented (Figure 3). If this option were true, it would be expected that the species would be less abundant and therefore placed further to the left in Figure 3.

Initial work with this concept using a smaller species list and plotting absolute numbers instead of proportions gave a poor rating for suballiance No. 25, which is described as being from the Richmond River (the next river valley to the north of the Clarence)(Rose 2012). This provided further evidence to support Option 1) above, however, with the revised methodology this is no longer as clear cut. Suballiance No. 25 is a dry rainforest type with a high rainfall, and as the lower Clarence floodplain has a relatively dry spring (Rose 2012, p. 24), it was expected that this suballiance would have a fit on the Clarence and perhaps it did. However, this is not a strong link and it can be argued that the data presented in Figure 3 could support the idea that at some time in the past the region directly to the north of the Clarence was a barrier for the north-south movement of rainforest species.

Floyd (1990, v.1 p 23) in setting up his classification of New South Wales Rainforests comments that:

It must be kept in mind at all times that the subformations, alliances and particularly the suballiances are merely nodes or fairly frequent clusters of species along a continuous graduation. Some areas will fall somewhere between two nodes or suballiances.

Keeping these comments in mind a conceptual model of the possible distribution of suballiances throughout the Clarence floodplain is proposed with the boundaries in the diagram acting as transition zones (Figure 4). In this model suballiance No. 4 occupies sections directly on the
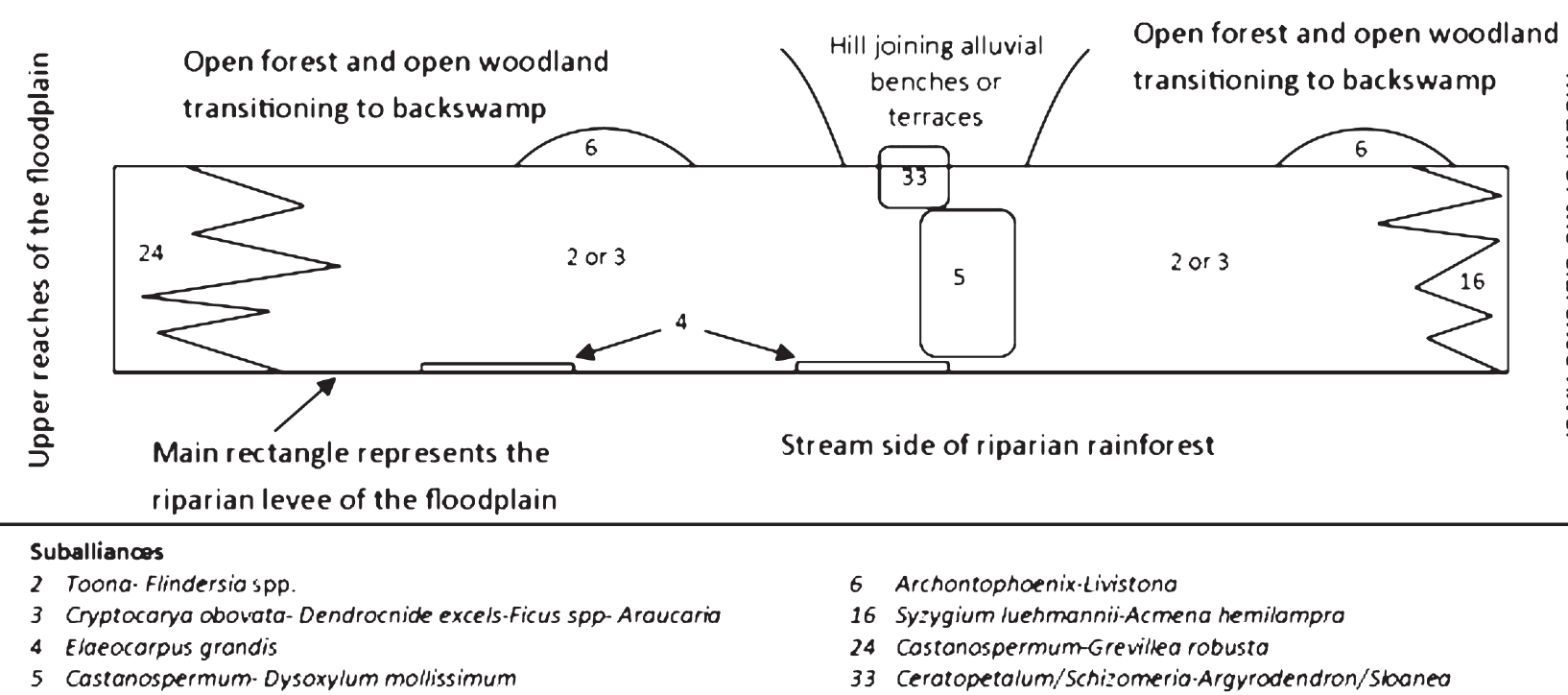
6 Archontophoenix-Livistono
16 Syzygium luehmannii-Acmena hemilampra
24 Costonospermum-Grevillea robusta
33 Cerotopetalum/Schizomeria-Argyrodendron/Stoaneo

Figure 4. Proposed conceptual model of the occurrence and arrangement of the various rainforest suballiances on the Clarence floodplain. 
riverbank, transitioning to the two major and one niche suballiance that occupy the bulk of the alluvial streamside levees. The two major suballiances are No. 2 and No. 3. Floyd indicates that suballiance No. 2 may suffer from seasonal moisture stress, which is a characteristic of the Clarence floodplain during spring. A climate and geomorphological (e.g. bank height, Rose 2012) gradient does exist along the Clarence floodplain and some species differentiation would be expected as a consequence. The corner trees from the portion plans provided some data on species distribution; however, only two rainforest species had more than four representatives, making any subregional suballiance delineation highly speculative.

Apart from Carron's Grafton brush species list (Appendix I), the only species location comments in the historical record refer to the Hoop pine, Araucaria cunninghamii, in the lower river:

(i) Hodgkinson (1845 p. 97) notes that: The brushes near the mouth of the Clarence are interspersed with the beautiful variety of pine I have already described...

(ii) Perry investigating a northern branch off the main river not far from the mouth (perhaps around Chatsworth Island via Middle Channel) found ... some nooks presenting pine brushes. The height of the pine trees, at the full growth, is about ninety feet, and they are as straight as an arrow. (Lang 1847, p. 45)

(iii) Pines were used as corner trees in four instances, all from Warregah Island. The only instance where pines were specifically referred to on portion plans was as a pine forest near the current day Maclean golf course (northern end of Woodford Island), which is upstream from where the above comments were made.

Floyd's (1990, v.2 microfiche) species lists indicate that Araucaria cunninghamii is present in suballiance No. 3 but not in suballiance No. 2, providing some support that at least on the lower floodplain that suballiance No. 3 may have been more dominant than suballiance No. 2 .
Floyd commented that the rainforest on Susan Island, located at the upper reaches of the floodplain, contains four emergent species typical of dry rainforest. As a consequence, the conceptual model includes a zone of transition at the upper end of the floodplain from the two major suballiances No. 2 and No. 3 into the dry rainforest suballiance No. 24. This suballiance is present in the upper reaches of the Clarence River and plausibly could have transitioned into the floodplain. Suballiance No. 24 rates very highly in Figure 3 and sits on the midline between less and more representative. This indicates that a lot of the less abundant species from this suballiance were known to those, who contributed to the historical species list. Most of these people would have been based in Grafton during their visit to the region and it is plausible that their knowledge of the rainforest species closer to Grafton would have been better than those further away. However, as Suballiance 24 does not sit further to the right in Figure 3, it is fair to place it as a transitional suballiance on the Clarence floodplain.

At the mouth of the Clarence a zone of transition to the littoral rainforest suballiance No. 16 is included. Rich (1996) has suggested that littoral rainforest can be found inland as far as $3.1 \mathrm{~km}$ and further inland along estuarine rivers (e.g. Stotts Island on the Tweed River is $15 \mathrm{~km}$ upstream and $8 \mathrm{~km}$ inland). The analysis of the historical data rates suballiance No. 16 on the midline between less and more representative, which is indicative of a transitional suballiance - the species are present to some extent, but as they are not fully suited, are not all that abundant.

The niche suballiance present in the main body of the riparian rainforest is suballiance No. 5, which is present on alluvial flats or benches that have been created by the weathering of an adjacent hill or plateau. A number of situations exist on the floodplain where the geomorphology is stream-bench-hill, without a backswamp in between e.g. near Maclean High School, where a remnant of this suballiance used to exist until destroyed by flying

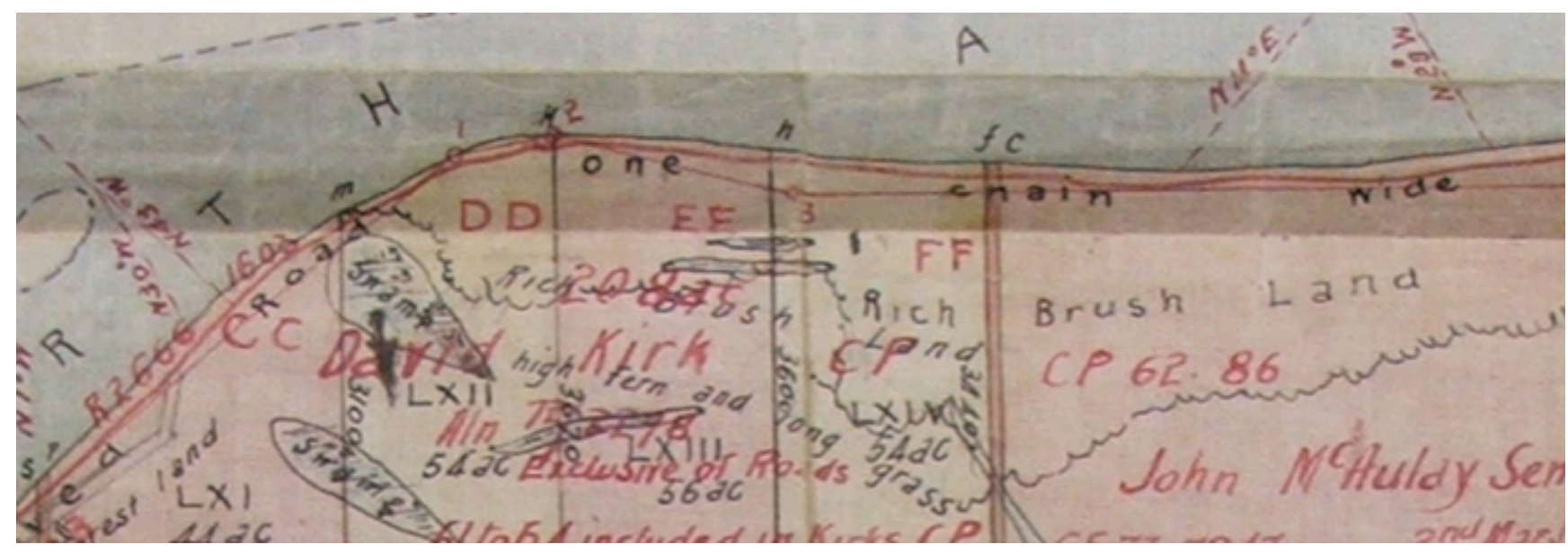

Figure 5 Portion plan of the northern part of Chatsworth Island showing a reference to 'high fern and long grass'. Surveyed 1862. (Department of Lands, Grafton, C62) 
foxes (Silver 2010). It is possible that this suballiance transitioned into the warm rainforest suballiance No. 33 from the bench into gullies in the adjacent hill. It has been included as such in the conceptual model.

Floyd (1990 v.2 p. 23) notes that there are two examples of suballiance No. 6 in the lower Clarence region, with one on the floodplain. An early newspaper article about Susan Island records among other plants that Bangalow palms (Archontophoenix cunninghamiana) are present (Clarence and Richmond Examiner and New England Advertiser, 20 January, 1880, p. 3). As expected this suballiance rates poorly in the historical data analysis (Figure 3) as only a few species have high abundance ratings (Appendix 4). From a habitat point of view suballiance No. 6 fits as a transition suballiance from the main body of the riparian rainforest to the backswamps. As noted previously, both Hodgkinson and Perry commented on the abundance of pines on the lower river. Hoop pines (Araucaria cunninghamii) were observed at Stotts Island (Tweed River, northern New South Wales) within one of the largest examples of suballiance No. 6, where they are present on slightly higher areas in amongst the palm trees (Floyd, 1990, v. 2 p. 22). There were no references to palm forests on the 1860 s portion plans. There were, however, many references to 'high fern' (e.g. Figure 5) in the areas where this suballiance may have been expected to be present but no documentation was found to confirm its identity (possibly Bracken Pteridium esculentum, Ed.).

As an aid to those using the suballiance conceptual model (Figure 4), the 45 most abundant species in Floyds (1990) species list from each suballiance as determined by the ranking system used in Table 1 is given in Appendix 4.

A total of 17 species from the historical list were not present in the 12 suballiances of interest. Most of these species were collected by Moore in 1861, at a time when there were still substantial areas of rainforest on the floodplain. A reason for their absence could be found for most of the species, however, two species were not able to be located in the Australian Plant Name Index and one (Cupaniopsis serrata) may have been totally lost to New South Wales. The presence of these species in the historical list indicate that the remaining rainforest remnants do not necessarily fully represent what was originally there. This is quite plausible, as the remnants are in locations that are not typical of the habitat of the majority of the original riparian rainforest. The conceptual model (Figure 4) cannot be classified as a complete solution, but based on the currently available evidence, as presented in this paper, it may be a fair representation of what may have been there.

\section{Conclusion}

We may never know the true species composition of the original riparian rainforest of the Clarence floodplain, but this paper has attempted to use the available information to generate a concept of what may have been there. Models do not always generate the correct answer. They do, however, provide a framework that promotes discussion and the basis for the construction of alternatives.

\section{Acknowledgements}

The guidance of Alison Specht, Michael Whelan and Brett Stubbs was greatly appreciated. Thanks to Miguel Garcia for tracking down Moore's list of rainforest species from the northern districts.

\section{References}

Carron, W (1872a) Timber Reserves in the Clarence River District. The Sydney Morning Herald. 19th August.

Carron, W (1872b) Timber Reserves (Report on - In Clarence, Richmond and Tweed River Districts). Legislative Assembly New South Wales: 861-872.

Flora of Australia Volume 11B (2001) Mimosaceae, Acacia part 2. ABRS/CSIRO Publishing, Melbourne.

Floyd, AG (1990) Australian Rainforests in New South Wales. Surrey Beatty and Sons, NSW National Parks and Wildlife Service.

Floyd, AG (2008) Rainforest tress of mainland south-eastern Australia. Terania Rainforest Publishing, Lismore, Australia.

Ensbey, F (2010) Clarence Valley Council Riparian Action Strategy. Clarence Valley Council, Grafton.

Hodgkinson, C (1845) Australia from Port Macquarie to Moreton Bay. T. and W. Boone, London.

King, CJ (1974) Moore, Charles (1820-1905), Australian Dictionary of Biography, Online Edition, Australian National University.

Lang, JD (1847) Cooksland in north-eastern Australia. Longman, Brown, Green and Longmans, London.

McFarlane, D (1924) A History of the Clarence River. complied from a series of articles in the Daily Examiner by Job (2005). Clarence River Historical Society Inc, Grafton, New South Wales.

Moore, C (1861a) Scrub Timbers of the Clarence and Richmond Districts. The Courier. Brisbane, Qld. 26 September 2-3.

Moore, C (1861b) Woods indigenous to the Northern district of the colony. London International Exhibition, 1862 : Catalogue of the natural and industrial products of New South Wales. pp. 27-32.

Moore, C (1867) Woods from the Northern Districts of the Colony. The Sydney Morning Herald. 21st February.

NSW Scientific Committee (1999) Lowland rainforest on floodplain in the NSW North Coast Bioregion - endangered ecological community - final, NSW Department of Environment and Conservation, Sydney. 
Rich, A (1996) What is littoral about rainforest? A study of floristic patterns in coastal rainforests of subtropical eastern Australia Faculty of Resource Science and Management. Lismore, Southern Cross University. Honours thesis: 120.

Rose, P (2012) Riparian vegetation on the Clarence Floodplian: historical insights as an aid for today's management, Southern Cross University, Lismore, Australia. M Sc. Thesis.

Rose, P, Specht, A, Whelan, M \& Stubbs, B (2010) Riparian vegetation change on the Clarence River floodplain. Australasian Journal of Environmental Management 17: 223-234.

Silver, V (2010) Draft Maclean flying-fox management strategy, prepared for Clarence Valley Council and Department of Environment and Climate Change and Water, GeoLINK, Lennox Head, New South Wales.

Stubbs, BJ (1996) A question of competing values: forest and timber conservation in New South Wales, 1838-1996, Southern Cross University, Lismore. PhD Thesis: pp 615.
Vader, J (1987) Red Gold: The tree that built a nation. New Holland Publishers (Australia) Pty Ltd. Frenches Forest NSW.

Wilson, P (2014a) Clarence Floodplain and Estuary Partnership Meeting Minutes $5^{\text {th }}$ June 2014, Clarence Valley Council, Grafton, NSW.

Wilson, P (2014b) Outcomes and actions from CF \& EP Workshop, $15^{\text {th }}$ October 2014, Clarence Valley Council, Grafton, NSW.

Manuscript accepted 25 November 2014

\section{Appendix 1. Historical species list - Brush (rainforest) species from the Clarence floodplain as recorded in the mid-19th century}

\section{Described}

Common names

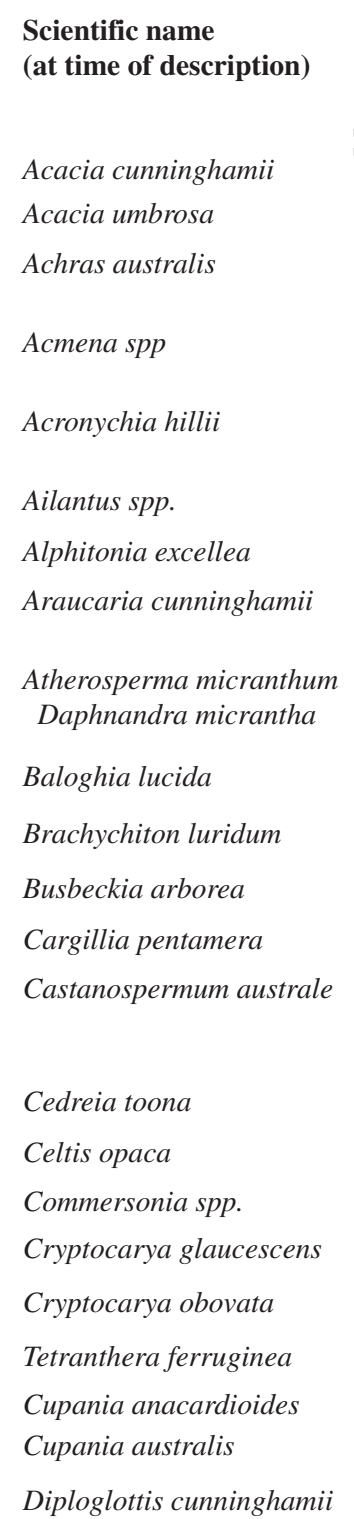
by (a)

Carron (1871)

(Wilson:

1841-42,
others:
1857-1870)
- $\quad$ Agundi-gundie
- Mountain ash

- $\quad$ Pine

$\begin{array}{ll}\text { - Tdun-dambie } & \text { pine } \\ \text { light yellow } \\ \text { wood }\end{array}$

$\begin{array}{ll}\text { - } & \text { Nun nala } \\ \text { - } & \text { sycamore }\end{array}$

- Tree Caper

- $\quad$ black myrtle

black-myrtle

- - Moreton Bay Chestnut or bean tree

$\begin{array}{lll}\text { - } & \text { Cedar } \quad \text { red cedar Cedar } \\ \text { - } & \text { Brown Kurrajong }\end{array}$

Surveyors

\section{Scientific name}

Likely current names from the Australian Plant Name Index

1857-1870)

Acacia trinervata

Acacia binervata

Pouteria australis

Myrtaceae

Sarcomelicope simplicifolia Yellowwood subsp. simplicifolia

$\begin{array}{ll}\text { Ailanthus triphysa } & \text { White bean } \\ \text { Alphitonia excelsa } & \text { Red ash } \\ \text { Araucaria cunninghamii } & \text { Hoop pine }\end{array}$

Daphnandra micrantha

Baloghia inophylla

Brachychiton discolor

Capparis arborea

Diospyros pentamera

Castanospermum australe

Manning River socketwood

Brush bloodwood

Brush kurrajong

Brush caper berry

Grey persimmon

Black bean
Red cedar

Native hackberry

Brown kurrajong

Silver sycamore

Cryptocarya obovata Pepperberry

Cupaniopsis anacardioides Tuckeroo

Diploglottis australis Native tamarind 
Described

by

\section{Scientific name (at time of description)}

Cupania pseud-orchis

Cupania semiglauca

Cupania serrata

Cupania xylocarpa

Diospyros spp.

Denhamia pittosporoides

Duboisia myoporoides

Dysoxylon fraserianum

Dysoxylon muelleri

Echinocarpus australis

Endiandra virens

Epicarpurus orientalis

Erythrina vespertilionis

Eugenia ventenatii

Euodia erythrococca

Ficus aspera

Ficus macrophylla

Flindersia australis

Geijera salicifolia

Geissois benthamii

Grevillea robusta

Harpullia pendula

Hartighsia rufa

Hodgkinsonia ovatiflora

Jambosa australis

Lophostemon australis

Mooria

campylosperma.

Morus brunoniana

Myrtus acmenoides

Myrtus melastom?e

Nephelium lanuginosum

Nephelium leiocarpum

Nephelium lucidum

Olea paniculata

Owenia venosa

Panax elegans

Pseudalangium spp.

•

$\bullet$

$\bullet$
$\bullet$

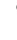

Common names

Surveyors

(Wilson:

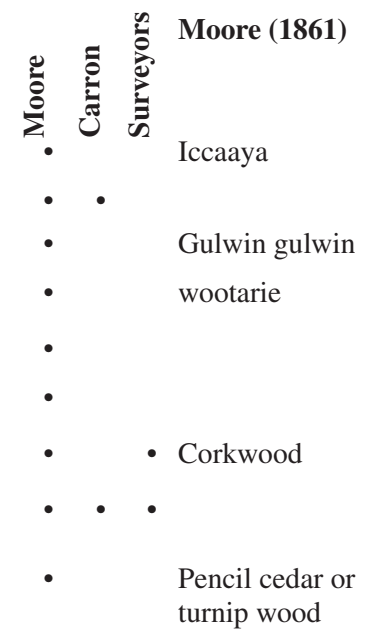

rosewood

1857-1870)

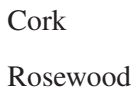

Cork

Rosewood

Jagera pseudorhus

Guioa semiglauca

Cupaniopsis serrata

Elattostachys xylocarpa

Diospyros spp

Denhamia pittosporoides

Duboisia myoporoides

Dysoxylum fraserianum

Dysoxylum mollissimum

Sloanea australis

Endiandra virens

Epicarpurus orientalis

Erythrina vespertilio

Syzygium floribundum

Large-leafed

water gum

- $\quad$ Small leafed fig
- $\quad$ Large leaved fig

- $\quad$ Ash, beech

- $\quad$ Balsam Capivi

tree

silky-oak

tulip-wood

Fig

Ash

Whitewood

Beech

Woggi-amabbie

- larribie

- Cherry of the

Clarence

- Urra wymbie

- lagaulbie

- $\quad$ - White myrtle

hickory

Hickory

- uroobie

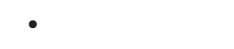

- Julip wood

- $\quad$ marblewood

- Tulip wood

- undambie

- Walm babie
Dinosperma erythrococcum Tingle-tongue

Ficus obliqua

Ficus macrophylla

Flindersia australis

Flindersia schottiana

Geijera salicifolia

Geissois benthamii

Gmelina leichhardtii

Grevillea robusta

Harpullia pendula

Dysoxylum rufum

Hodgkinsonia ovatiflora

Syzygium australe

Lophostemon confertus

Citronella moori

Streblus brunonianus

Gossia acmenoides

Rhodamnia rubescens

Alectryon subcinereus

Olea paniculata

Owenia venosa

Polyscias elegans

Alangium villosum subsp. polyosmoides Small leaved fig

Moreton Bay fig

Crows ash

\section{Common name}

Foambark Tree

Wild quince

Smooth tuckeroo

White tamarind

Orange boxwood

Cork

Rosewood, Rose mahogany

Miva mahogany

Blush alder

White apple

Grey corkwood

Weeping satinash

Green satinheart

Brush mahogany

White beech

Southern silky oak

Tulipwood

Rusty mahogany

Golden ash

Brush cherry

Brush box

Soapy box

Whalebone tree Ironwood

Brush turpentine

Wild quince, bird's eye

Native olive

Tulipwood

Celery wood

Black muskheart 
Described

by

Common names

(a)

Scientific name
(at time of description)
Rhus rhodanthema

(

Rottlera discolor

Rottlera tinctoria

Schmidelia anodonta

Stenocarpus salignus

Stenocarpus sinuatue

Synoum glandulosum

Tabern? emontana spp.

Tarrietia argyrodendron

Trochocarpa laurina

Urtica gigas

Urtica photiniophylla

Vitex spp

Wistaria megasperma

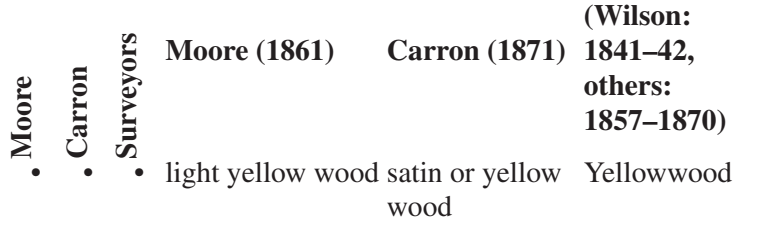

Surveyors

(Wilson:

Scientific name

Common name

Rhodosphaera rhodanthema Tulip satinwood

Mallotus discolor

Yellow kamala

Mallotus philippensis

Mischocarpus anodontus

Orange kamala

- gomphan

- $\quad$ beefwood or silky oak

Stenocarpus salignus

Pear fruited tamarind

Stenocarpus sinuatus

Red silky oak

beefwood or

silky oak

$\begin{array}{ll}- & \text { Rosewood } \\ . & \text { Bitter bark } \\ \text { - } & \text { Iron wood or } \\ & \text { byong }\end{array}$

$$
\text { - } \quad \text { bush cherry }
$$
- $\quad$ Large Nettle tree
- Small-leaved nettle

- Beech-tree

$\bullet$

$\begin{array}{ll}\text { Synoum glandulosum } & \text { Scentless rosewood } \\ \text { Heritiera trifoliolatum } & \text { Brown tulip oak }\end{array}$

Trochocarpa laurina

Dendrocnide excelsa Giant stinging tree

Dendrocnide photinophylla Shining leaved stinging tree

Premna lignum-vitae Yellow hollywood

Callerya megasperma Native wistaria

\section{Appendix 2. The 60 species of the total of 77 species from the historical list (Appendix 1) also present in Floyd's (1990) species list.}

$\begin{array}{ll}\text { Family } & \text { Species } \\ \text { Alangiaceae } & \text { Alangium villosum } \\ \text { Anacardiaceae } & \text { Rhodosphaera rhodanthema } \\ \text { Araliaceae } & \text { Polyscias elegans } \\ \text { Araucariaceae } & \text { Araucaria cunninghamii } \\ \text { Cannabaceae } & \text { Celtis paniculata } \\ \text { Capparaceae } & \text { Capparis arborea } \\ \text { Cardiopteridaceae } & \text { Citronella moorei } \\ \text { Cunoniaceae } & \text { Geissois benthamii } \\ \text { Ebenaceae } & \text { Diospyros pentamera } \\ \text { Elaeocarpaceae } & \text { Sloanea australis } \\ \text { Epacridaceae } & \text { Trochocarpa laurina } \\ \text { Euphorbiaceae } & \text { Baloghia inophylla } \\ & \text { Mallotus discolor } \\ \text { Fabaceae } & \text { Mallotus philippensis } \\ \text { Lauraceae } & \text { Castanospermum australe } \\ & \text { Cryptocarya glaucescens } \\ & \text { Cryptocarya obovata } \\ \text { Meliaceae } & \text { Endiandra virens } \\ & \text { Dyoxylum fraserianum } \\ & \text { Dysoxylum mollissimum } \\ & \text { Dyoxylum rufum } \\ \text { Monimiaceae } & \text { Synoum glandulosum } \\ \text { Moraceae } & \text { Toona ciliata } \\ & \text { Daphnandra micrantha } \\ & \text { Ficus macrophylla } \\ \text { Ficus obliqua } \\ \text { Streblus brunonianus } \\ \end{array}$

Name in 1990

Fa. Ulmaceae

Fa. Icacinaceae

Dysoxylum muelleri

Toona australis

Fa. Atherospermataceae

\author{
Common name \\ Black muskheart \\ Deep yellowwood \\ Celery wood \\ Hoop pine \\ Native hackberry \\ Native pomegranate \\ Soapy Box \\ Red carabeen \\ Grey persimon \\ Mainden's blush \\ Tree heath \\ Brush bloodwood \\ Yellow kamalla \\ Orange kamalla \\ Black bean \\ Jackwood \\ Pepperberry \\ White apple \\ Rosewood \\ Red bean \\ Hairy Rosewood \\ Scentless rosewood \\ Red cedar \\ Socketwood \\ Moreton Bay fig \\ Small leaved fig \\ Whalebone tree
}




\begin{tabular}{|c|c|c|c|}
\hline Family & Species & Name in 1990 & Common name \\
\hline \multirow[t]{5}{*}{ Myrtaceae } & Gossia acmenoides & Austromyrtus acmenoides & Scrub ironwood \\
\hline & Lophostemon confertus & & Brush box \\
\hline & Rhodamnia rubescens & & Scub turpentine \\
\hline & Syzygium australe & & Brush cherry \\
\hline & Syzgium floribundum & Waterhousea floribunda & Weeping myrtle \\
\hline Oleraceae & Olea paniculata & & Native olive \\
\hline \multirow[t]{3}{*}{ Proteaceae } & Grevillea robusta & & Silky oak \\
\hline & Stenocarpus salignus & & Scrub beefwood \\
\hline & Stenocarpus sinuatus & & Wheel of fire tree \\
\hline Rhamnaceae & Alphitonia excelsa & & Red ash \\
\hline Rubiaceae & Hodgkinsonia ovatiflora & & Golden ash \\
\hline \multirow[t]{4}{*}{ Rutaceae } & Dinosperma erythrococcum & Melicope erthrococca & Tingletongue \\
\hline & Flindersia australis & & Teak \\
\hline & Flindersia schottiana & & Bumpy ash \\
\hline & Sarcomelicope simplicifolia & & Yellow acronychia \\
\hline \multirow[t]{8}{*}{ Sapindaceae } & Alectryon subcinereus & & Wild quince \\
\hline & Cupaniopsis anacardioides & & Tuckeroo \\
\hline & Diploglottis australis & & Tamarind \\
\hline & Elattostachys xylocarpa & & Short-leaf beetroot \\
\hline & Guioa semiglauca & & Guioa \\
\hline & Harpullia pendula & & Tulipwood \\
\hline & Jagera pseudohus & & Foambark \\
\hline & Mischocarpus anodontus & & Few-leaved brush apple \\
\hline Sapotaceae & Pouteria australis & Planchonella australis & Black apple \\
\hline Simaroubaceae & Ailanthus triphysa & & White bean \\
\hline Solenaceae & Duboisia myoporoides & & Soft corkwood \\
\hline \multirow[t]{3}{*}{ Sterculiaceae } & Heritiera trifoliolatum & Argyrodendron trifoliolatum & White booyong \\
\hline & Brachychiton discolor & & Lacebark tree \\
\hline & Commersonia bartramia & & Brown kurrajong \\
\hline \multirow[t]{2}{*}{ Urticaceae } & Dendrocnide excelsa & & Giant stinging tree \\
\hline & Dendrocnide photinophylla & & Shining-leaved stinging tr \\
\hline \multirow[t]{2}{*}{ Verbenaceae } & Gmelina leichhardtii & & white beech \\
\hline & Premna lignum-vitae & & Lignum-vitae \\
\hline
\end{tabular}

Appendix 3. The historical list of species (Appendix 2) with average abundance data using the rating in Table 2 applied to the abundance data taken from Floyd (1990).

\begin{tabular}{|c|c|c|c|c|c|c|c|c|c|c|c|c|}
\hline Species & 1 & 2 & 3 & 4 & 5 & 6 & 16 & 23 & 24 & 25 & 26 & 33 \\
\hline Ailanthus triphysa & 1.5 & & & & & & 0.8 & 0.2 & 0.3 & & & 0.2 \\
\hline Alangium villosum & 1.5 & 3.5 & 2.8 & 1.3 & 1.5 & 0.2 & 1 & 0.2 & & & & 1.2 \\
\hline Alectryon subcinereus & 0.5 & 0.5 & 0.6 & 1 & & & & 2.6 & 1.3 & & 0.3 & 0.8 \\
\hline Alphitonia excelsa & 1.8 & 2 & 2.6 & 0.3 & 1.8 & 0.2 & 0.8 & 2.6 & 0.3 & 3 & 4.8 & 2.4 \\
\hline Araucaria cunninghamii & & & 1.4 & & & 0.6 & 1.5 & 0.6 & 0.3 & & & \\
\hline Argyrodendron trifoliolatum & 9.0 & 1 & 2.4 & 0.3 & 2.3 & & & 0.6 & 2 & & & 1.2 \\
\hline Austromyrtus acmenoides & & 1.5 & 0.2 & & & & & 0.8 & & 2.3 & & 0.2 \\
\hline Baloghia inophylla & 2.5 & 1.5 & 1.2 & & 1 & 0.6 & 0.3 & 3.8 & 5.3 & & 0.8 & 2.6 \\
\hline Brachychiton discolor & & 0.5 & 1.8 & & & & & 1.2 & 0.3 & & & \\
\hline Capparis arborea & 1.5 & & 2.6 & 1 & 1 & & & 3.8 & & 4 & & \\
\hline Castanospermum australe & 1.0 & & 2.6 & 1 & 10 & & & & 8.7 & 3 & & 1.2 \\
\hline Celtis paniculata & 05 & 1.5 & 0.8 & 0.3 & 1 & & 1.8 & 0.4 & 1 & & & \\
\hline Citronella moorei & 1.3 & 0.5 & & 2 & 0.8 & & & 1.2 & & & & 1 \\
\hline Commersonia bartramia & 1.0 & 1.5 & 0.8 & 0.3 & 0.3 & & 1.5 & 2 & 0.3 & & & 0.6 \\
\hline Cryptocarya glaucescens & & 1.5 & & 1.3 & 0.3 & 0.6 & 0.3 & 0.2 & & & 3 & 2.8 \\
\hline Cryptocarya obovata & 1.0 & 6 & 4 & 1.7 & 2.8 & 1 & & 0.6 & 2.3 & 4 & 0.8 & 1.4 \\
\hline Cupaniopsis anacardioides & & & 0.2 & & 0.3 & 0.2 & 7.3 & 3.2 & & & & \\
\hline Daphnandra micrantha & 2.5 & 3 & 1.8 & 3.3 & & 0.6 & & 1.4 & 3 & & 1.5 & 2.4 \\
\hline Dendrocnide excelsa & 3.8 & 5 & 6 & 1.3 & 1.8 & & & 3 & 2 & & & 1.6 \\
\hline
\end{tabular}




\begin{tabular}{|c|c|c|c|c|c|c|c|c|c|c|c|c|}
\hline Species & 1 & 2 & 3 & 4 & 5 & 6 & 16 & 23 & 24 & 25 & 26 & 33 \\
\hline Dendrocnide photinophylla & 2.8 & 2 & 2 & 1.3 & 2.3 & & 4.5 & 0.6 & 1 & & & 0.6 \\
\hline Diospyros pentamera & 3.3 & 3 & 2.4 & & 1.8 & 0.6 & 3.5 & 3.8 & 1 & 1 & & 3 \\
\hline Diploglottis australis & 2.5 & 3 & 2 & 3 & 2.5 & & 0.8 & 2.2 & 1.3 & 1.3 & 0.8 & 2.2 \\
\hline Duboisia myoporoides & 1.5 & & 0.2 & & & & & & & & & 0.8 \\
\hline Dyoxylum fraserianum & 2.0 & 2 & 0.2 & 1 & 1.5 & & 0.8 & 2.4 & 2 & & 0.8 & 1.6 \\
\hline Dyoxylum mиelleri & 2.5 & 0.5 & 1.2 & 3.3 & 5 & 0.8 & 1 & 0.6 & & & & 0.6 \\
\hline Dyoxylum rufum & 0.3 & 4.5 & 2.2 & 0.3 & 0.3 & & 0.3 & 0.2 & 1 & & & 1.2 \\
\hline Elattostachys xylocarpa & & & & & & & & 0.6 & 0.3 & & & \\
\hline Endiandra virens & 0.8 & & & & & & & & & & & 0.2 \\
\hline Ficus macrophylla & 2.3 & 5 & 8.4 & 1 & 0.8 & & & 2.6 & 1.3 & & & 0.2 \\
\hline Ficus obliqua & 2 & 1.5 & 3 & 0.3 & & 0.2 & 1.8 & 0.8 & & & & \\
\hline Flindersia australis & 0.8 & & 0.4 & & 0.8 & & & 0.6 & & & & 0.2 \\
\hline Flindersia schottiana & & & 0.8 & 0.3 & 2.3 & & 4.8 & 0.6 & & & & 0.8 \\
\hline Geissois benthamii & 3.8 & & & 2 & 3.3 & & & & & & & 5.2 \\
\hline Gmelina leichhardtii & 0.8 & & 0.2 & 1.3 & 0.3 & 0.2 & 1 & 0.6 & 0.3 & & 0.3 & 1.6 \\
\hline Grevillea robusta & & 3 & 1.4 & & & & & & 4.7 & 1.7 & 2.5 & \\
\hline Guioa semiglauca & 2.5 & 0.5 & 2 & 1.3 & 1.5 & 0.6 & 4.5 & 4.4 & 1.3 & 2 & 2.3 & 2.4 \\
\hline Harpullia pendula & 0.3 & 3.5 & 2.8 & & 0.3 & 0.2 & 0.8 & & & & & \\
\hline Hodgkinsonia ovatiflora & 0.5 & 0.5 & 0.8 & 1 & 0.8 & 1.2 & 4.3 & 0.4 & 0.3 & 1.3 & & 0.2 \\
\hline Jagera pseudohus & 1.8 & 3 & 3 & 0.3 & 2.3 & 0.6 & 1.3 & 1.4 & & 2 & 1 & 0.8 \\
\hline Lophostemon confertus & 4.5 & 1.5 & & 2.3 & 1.8 & 0.6 & 3 & 1.2 & 0.3 & & & 3 \\
\hline Malotus discolor & 2.5 & 1.5 & 0.6 & & 1.5 & & 1.5 & 0.6 & & & & 0.2 \\
\hline Malotus philippensis & 1.5 & 1.5 & 4.4 & 2 & 1.5 & & & 6 & 4 & 5.3 & & 0.6 \\
\hline Melicope erythrococca & & & & & & & & 0.6 & & & & \\
\hline Mischocarpus anodontus & & & & & & 0.2 & & & & & & \\
\hline Olea paniculata & 0.3 & & 0.4 & & & 0.6 & 1 & 3.8 & 0.7 & & & \\
\hline Planchonella australis & 1.8 & 0.5 & 2.4 & 1 & 1.3 & & 1 & 2 & & 0.7 & 1 & 1.6 \\
\hline Polyscias elegans & 2.0 & 3 & 1.4 & 1 & 1.8 & 0.6 & 2 & 1.6 & 0.3 & & & 1.4 \\
\hline Premna lignum-vitae & & & & & & & & & 1 & & & \\
\hline Rhodamnia rubescens & 0.5 & 3 & & & 1 & 0.6 & & 1.2 & & & & 2.4 \\
\hline Rhodosphaera rhodanthema & & & & & & & & & 1 & & & \\
\hline Sarcomelicope simplicifolia & 0.8 & & 0.4 & & 1.8 & & 1.5 & 2 & & & & 0.4 \\
\hline Sloanea australis & 5.8 & & 2 & 7.7 & 3.3 & 2.6 & & 0.6 & & & 0.3 & 3.2 \\
\hline Stenocarpus salignus & & & & & & & & 0.4 & & & & 1.6 \\
\hline Stenocarpus sinuatus & 0.8 & & 0.6 & 1 & 0.8 & 0.2 & & 0.6 & & & & 0.2 \\
\hline Streblus brunonianus & 1.0 & 5 & 5.6 & & 1.5 & & & 9.2 & 3.3 & 8.7 & 0.3 & 0.2 \\
\hline Synoum glandulosum & & & & 2 & 0.8 & 1.8 & 0.3 & 0.6 & & & 0.8 & 3 \\
\hline Syzygium australe & 1.5 & & 1 & 2 & 0.3 & & 1.8 & 0.8 & 4 & 1.3 & & 0.8 \\
\hline Toona australis & 0.3 & 5 & 1.4 & 5.3 & 2.3 & 0.2 & & 1 & 2.3 & & 0.8 & 0.6 \\
\hline Trochocarpa laurina & & & & & & 2.6 & 2.3 & 0.6 & & & & 2.8 \\
\hline Waterhousea floribunda & & & 1.8 & & & & & 0.6 & & & & \\
\hline Sum of average abundance values & 82 & 83 & 87 & 56 & 69 & 18 & 58 & 84 & 59 & 42 & 22 & 63 \\
\hline Total abundance value & 225 & 196 & 193 & 160 & 156 & 86 & 193 & 214 & 132 & 126 & 107 & 213 \\
\hline $\begin{array}{l}\text { Percentage of historial list of the total } \\
\text { abundance }\end{array}$ & $37 \%$ & $42 \%$ & $45 \%$ & $35 \%$ & $44 \%$ & $21 \%$ & $30 \%$ & $39 \%$ & $45 \%$ & $33 \%$ & $20 \%$ & $30 \%$ \\
\hline No. of species (max. 60) & 44 & 35 & 45 & 34 & 41 & 26 & 31 & 52 & 33 & 15 & 18 & 45 \\
\hline Total No. of species & 161 & 93 & 146 & 103 & 134 & 99 & 95 & 166 & 75 & 52 & 80 & 184 \\
\hline $\begin{array}{l}\text { Percentage of historial list of the total no. } \\
\text { of species }\end{array}$ & $27 \%$ & $38 \%$ & $31 \%$ & $33 \%$ & $31 \%$ & $26 \%$ & $33 \%$ & $31 \%$ & $44 \%$ & $29 \%$ & $23 \%$ & $24 \%$ \\
\hline
\end{tabular}




\section{Appendix 4. Rainforest trees by suballiance that have been sorted by abundance.}

These lists have been created from Floyd's species list (Floyd 1990, v. 2 microfiche) and have been sorted so that the top 45 most abundant species from the represented sites are listed. These could be the species to be used to start any rainforest recreation activities. This assumes that the more abundant species are the more successful in the ecological niche for that particular suballiance and therefore have the greatest chance of becoming established. These lists would be used in conjunction with the model of the location of the suballiances on the floodplain as an aid in species selection for any given site on the floodplain.

The lists show the species name using the 1990 names used in Floyd (1990). The abundance rating is shown for each of the listed sites and the average rating across all sites. In addition, the highest abundance rating for all sites is shown.

Table 2 (from main document) Numerical rating values applied to Floyd's (1990 v. 1 p. 23) abundance ratings.

$\begin{array}{ll}\text { Abundance rating } \\ \text { VC } & \text { Very common } \\ \text { C } & \text { Common } \\ \text { O } & \text { Occasional } \\ \text { R } & \text { Rare }\end{array}$

Suballiance No. 2 Toona - Flindersia spp.

\section{Basis for abundance rating}

Top 1-6 most common species

More than 5 individuals

2 to about 5 individuals

1 only seen

\section{Numerical rating}

10
6
3
1

\author{
Site Location \\ 1 Stotts Is. N.R. \\ 2 Hortons Ck., Leasehold
}

\begin{tabular}{|c|c|c|}
\hline Family & Genus & Species \\
\hline Sapindaceae & Elattostachys & nervosa \\
\hline Lauraceae & Cryptocarya & obovata \\
\hline Rutaceae & Flindersia & schottina \\
\hline Ulmaceae & Aphananthe & philippinensis \\
\hline Moraceae & Ficus & macrophylla \\
\hline Moraceae & Streblus & brunonianus \\
\hline Urticaceae & Dendrocnide & excelsa \\
\hline Meliaceae & Melia & azedarach var. australasica \\
\hline Meliaceae & Toona & australis \\
\hline Sterculiaceae & Argyrodendron & actinophyllum \\
\hline Moraceae & Ficus & coronata \\
\hline Meliaceae & Dyoxylum & rufum \\
\hline Sapindaceae & Harpullia & pendula \\
\hline Alangiaceae & Alangium & villosum \\
\hline Podocacarpaceae & Podocarpus & elatus \\
\hline Arecaceae & Archontophoenix & cunninghamiana \\
\hline Proteaceae & Grevillea & robusta \\
\hline Atherospermataceae & Daphnandra & micrantha \\
\hline Lauraceae & Endiandra & muelleri \\
\hline Lauraceae & Neolitsea & dealbata \\
\hline Euphorbiaceae & Cleistanthus & cunnunghamii \\
\hline Euphorbiaceae & Croton & verreauxii \\
\hline Euphorbiaceae & Drypetes & australasica \\
\hline Celastraceae & Denhamia & celastroides \\
\hline Sapindaceae & Diploglottis & australis \\
\hline Sapindaceae & Jagera & pseudohus \\
\hline Elaeocarpaceae & Elaeocarpus & grandis \\
\hline Elaeocarpaceae & Elaeocarpus & obovatus \\
\hline Myrtaceae & Austromyrtus & bidwillii \\
\hline Myrtaceae & Rhodamnia & rubescens \\
\hline Araliaceae & Polyscias & legans \\
\hline
\end{tabular}

Common
Beetroot
Pepperberry
Bumpy ash
Native elm
Moreton bay fig
Whalebone tree
Giant stinging tree
White cedar
Red cedar
Black booyong
Creek sandpaper fig
Hairy Rosewood
Tulipwood
Black muskheart
Brown pine
Bangalow palm
Silky oak
Socketwood
Green-leaved rose walnut
White bolly gum
Cleistanthus
Green native cascarilla
Yellow tulip
Orange boxwood
Tamarind
Blue fig

\begin{tabular}{|c|c|c|c|}
\hline \multicolumn{2}{|c|}{ Site } & \multirow{2}{*}{$\begin{array}{l}\text { Av. abund. } \\
\text { ratings }\end{array}$} & \multirow{2}{*}{$\begin{array}{l}\text { Max of } \\
\text { abund. } \\
\text { ratings }\end{array}$} \\
\hline 1 & 2 & & \\
\hline 3 & 10 & 6.5 & 10 \\
\hline 6 & 6 & 6 & 6 \\
\hline 6 & 6 & 6 & 6 \\
\hline 10 & & 5 & 10 \\
\hline 10 & & 5 & 10 \\
\hline \multirow[t]{4}{*}{10} & & 5 & 10 \\
\hline & 10 & 5 & 10 \\
\hline & 10 & 5 & 10 \\
\hline & 10 & 5 & 10 \\
\hline 10 & & 5 & 10 \\
\hline 6 & 3 & 4.5 & 6 \\
\hline 6 & 3 & 4.5 & 6 \\
\hline 6 & 1 & 3.5 & 6 \\
\hline 1 & 6 & 3.5 & 6 \\
\hline 6 & & 3 & 6 \\
\hline \multirow[t]{5}{*}{3} & 3 & 3 & 3 \\
\hline & 6 & 3 & 6 \\
\hline & 6 & 3 & 6 \\
\hline & 6 & 3 & 6 \\
\hline & 6 & 3 & 6 \\
\hline 6 & & 3 & 6 \\
\hline 3 & 3 & 3 & 3 \\
\hline \multirow[t]{2}{*}{6} & & 3 & 6 \\
\hline & 6 & 3 & 6 \\
\hline 3 & 3 & 3 & 3 \\
\hline 3 & 3 & 3 & 3 \\
\hline 6 & & 3 & 6 \\
\hline 6 & & 3 & 6 \\
\hline \multirow[t]{2}{*}{3} & 3 & 3 & 3 \\
\hline & 6 & 3 & 6 \\
\hline 3 & 3 & 3 & 3 \\
\hline
\end{tabular}




\begin{tabular}{|c|c|c|c|c|c|c|}
\hline Sapotaceae & Planchonella & laurifolia & Blush coondoo & 6 & & 3 \\
\hline Ebenaceae & Diospyros & pentamera & Grey persimon & 3 & 3 & 3 \\
\hline Urticaceae & Dendrocnide & photinophylla & Shining-leaved stinging tree & 1 & 3 & 2 \\
\hline Rutaceae & Acronychia & oblongifolia & Common acronychia & 1 & 3 & 2 \\
\hline Meliaceae & Dyoxylum & fraserianum & Rosewood & 1 & 3 & 2 \\
\hline Rhamnaceae & Alphitonia & excelsa & Red ash & 3 & 1 & 2 \\
\hline Ulmaceae & Celtis & paniculata & Native hackberry & 3 & & 1.5 \\
\hline Moraceae & Ficus & fraseri & Sandpaper fig & 3 & & 1.5 \\
\hline Moraceae & Ficus & obliqua & Small-leaved fig & 3 & & 1.5 \\
\hline Moraceae & Ficus & virens var. sublanceolata & White fig & 3 & & 1.5 \\
\hline Moraceae & Ficus & watkinsiana & Strangler fig & & 3 & 1.5 \\
\hline Lauraceae & Beilschmiedia & obtusifolia & Hard bolly gum & 3 & & 1.5 \\
\hline
\end{tabular}

\section{Suballiance No. 3 Cryptocarya obovata - Dendrocnide excels - Ficus spp - Araucaria}

Site
1
2
3
4
5

Location

1 Stotts Is. N.R.

2 Boat Harbour N.R.

Susan Island. N.R.

Bellingen Is. Rec. Res.

Wingham Brush Rec. \& Flora Res.

\begin{tabular}{|c|c|c|c|c|c|c|c|c|c|c|}
\hline \multirow[b]{2}{*}{ Family } & \multirow[b]{2}{*}{ Genus } & \multirow[b]{2}{*}{ Species } & \multirow[b]{2}{*}{ Common } & \multicolumn{5}{|c|}{ Site } & \multirow{2}{*}{$\begin{array}{l}\text { Av. } \\
\text { abund. } \\
\text { ratings }\end{array}$} & \multirow{2}{*}{$\begin{array}{l}\text { Max o } \\
\text { abund } \\
\text { ratings }\end{array}$} \\
\hline & & & & 1 & 2 & 3 & 4 & 5 & & \\
\hline Moraceae & Ficus & macrophylla & Moreton bay fig & 10 & 6 & 10 & 6 & 10 & 8.4 & 10 \\
\hline Ulmaceae & Aphananthe & philippinensis & Native elm & 10 & 10 & 6 & & 10 & 7.2 & 10 \\
\hline Urticaceae & Dendrocnide & excelsa & Giant stinging tree & & & 10 & 10 & 10 & 6 & 10 \\
\hline Moraceae & Streblus & brunonianus & Whalebone tree & 6 & 6 & 10 & & 6 & 5.6 & 10 \\
\hline Meliaceae & Melia & \multicolumn{2}{|c|}{ azedarach var. australasica White cedar } & & 3 & 3 & 6 & 10 & 4.4 & 10 \\
\hline Euphorbiaceae & Malotus & philippensis & Orange kamalla & 3 & 10 & 6 & & 3 & 4.4 & 10 \\
\hline Moraceae & Ficus & coronata & Creek sandpaper fig & 1 & 3 & 6 & 10 & 1 & 4.2 & 10 \\
\hline Lauraceae & Cryptocarya & obovata & Pepperberry & 3 & 10 & 1 & 3 & 3 & 4 & 10 \\
\hline Lauraceae & Endiandra & pubens & White bark walnut & & 10 & & 6 & & 3.2 & 10 \\
\hline Moraceae & Ficus & obliqua & Small-leaved fig & 3 & 6 & & 6 & & 3 & 6 \\
\hline Sapindaceae & Jagera & pseudohus & Foambark & & 6 & 3 & 6 & & 3 & 6 \\
\hline Sapindaceae & Harpullia & pendula & Tulipwood & 3 & 1 & 10 & & & 2.8 & 10 \\
\hline Alangiaceae & Alangium & villosum & Black muskheart & & 1 & & 3 & 10 & 2.8 & 10 \\
\hline Capparaceae & Capparis & arborea & Native pomegranate & & 6 & 1 & & 6 & 2.6 & 6 \\
\hline Fabaceae & Castanospermum & australe & Black bean & & 6 & 3 & 1 & 3 & 2.6 & 6 \\
\hline Rutaceae & Euodia & micrococca & White euodia & & 6 & & 6 & 1 & 2.6 & 6 \\
\hline Rhamnaceae & Alphitonia & excelsa & Red ash & 3 & 6 & 3 & & 1 & 2.6 & 6 \\
\hline Elaeocarpaceae & Elaeocarpus & obovatus & Blueberry ash & 6 & 3 & 3 & & 1 & 2.6 & 6 \\
\hline Myrtaceae & Eucalyptus & tereticornis & Forest red gum & & 3 & 10 & & & 2.6 & 10 \\
\hline Myrtaceae & Syzygium & francisii & Giant water-gum & 6 & 6 & & 1 & & 2.6 & 6 \\
\hline Sterculiaceae & Argyrodendron & trifoliolatum & White booyong & & 6 & & 6 & & 2.4 & 6 \\
\hline Sapotaceae & Planchonella & australis & Black apple & & 6 & & & 6 & 2.4 & 6 \\
\hline Ebenaceae & Diospyros & pentamera & Grey persimon & 3 & & 3 & 3 & 3 & 2.4 & 3 \\
\hline Lauraceae & Cinnamomum & oliveri & Oliver's sasafrass & & 10 & & 1 & & 2.2 & 10 \\
\hline Meliaceae & Dyoxylum & rufum & Hairy Rosewood & & 3 & 1 & 1 & 6 & 2.2 & 6 \\
\hline Arecaceae & Archontophoenix & cunninghamiana & Bangalow palm & 10 & & & & & 2 & 10 \\
\hline Moraceae & Ficus & watkinsiana & Strangler fig & & 3 & 1 & 6 & & 2 & 6 \\
\hline Urticaceae & Dendrocnide & photinophylla & Shining-leaved stinging tree & 1 & 6 & & 3 & & 2 & 6 \\
\hline Lauraceae & Neolitsea & dealbata & White bolly gum & & 3 & 1 & 3 & 3 & 2 & 3 \\
\hline Mimosaceae & Pararchidendron & pruinosum & Snow-wood & & 1 & 3 & 3 & 3 & 2 & 3 \\
\hline Sapindaceae & Diploglottis & australis & Tamarind & & 3 & & 6 & 1 & 2 & 6 \\
\hline Sapindaceae & Guioa & semiglauca & Guioa & 1 & 3 & & 3 & 3 & 2 & 3 \\
\hline Elaeocarpaceae & Sloanea & australis & Mainden's blush & & & & 10 & & 2 & 10 \\
\hline Atherospermatac & Daphnandra & micrantha & Socketwood & & 3 & & & 6 & 1.8 & 6 \\
\hline
\end{tabular}




$\begin{array}{lll}\text { Lauraceae } & \text { Endiandra } & \text { muelleri } \\ \text { Lauraceae } & \text { Litsea } & \text { australis } \\ \text { Euphorbiaceae } & \text { Drypetes } & \text { australasica } \\ \text { Sapindaceae } & \text { Elattostachys } & \text { nervosa } \\ \text { Sterculiaceae } & \text { Brachychiton } & \text { discolor } \\ \text { Myrtaceae } & \text { Waterhousea } & \text { floribunda } \\ \text { Araucariaceae } & \text { Araucaria } & \text { cunninghamii } \\ \text { Moraceae } & \text { Ficus } & \text { fraseri } \\ \text { Proteaceae } & \text { Grevillea } & \text { robusta }\end{array}$

Green-leaved rose walnut
Brown bolly gum
Yellow tulip
Beetroot
Lacebark tree
Weeping myrtle
Hoop pine
Sandpaper fig
Silky oak

$\begin{array}{lllllll} & 6 & 3 & & & 1.8 & 6 \\ & 6 & 3 & & & 1.8 & 6 \\ 6 & 3 & & & & 1.8 & 6 \\ & 3 & & 3 & 3 & 1.8 & 3 \\ & 3 & 6 & & & 1.8 & 6 \\ & & & 6 & 3 & 1.8 & 6 \\ 3 & 3 & & & 1 & 1.4 & 3 \\ 1 & 3 & 3 & & & 1.4 & 3 \\ & 3 & 1 & 3 & & 1.4 & 3\end{array}$

\section{Suballiance No. 4 Elaeocarpus grandis}

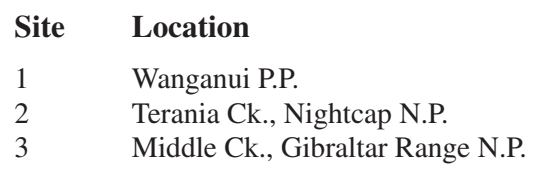

\begin{tabular}{|c|c|c|}
\hline Family & Genus & Species \\
\hline Arecaceae & Archontophoenix & cunninghamiana \\
\hline Elaeocarpaceae & Sloanea & australis \\
\hline Elaeocarpaceae & Elaeocarpus & grandis \\
\hline Escelloniaceae & Cuttsia & viburnea \\
\hline Meliaceae & Toona & australis \\
\hline Moraceae & Ficus & coronata \\
\hline Atherospermataceae & Daphnandra & micrantha \\
\hline Lauraceae & Cryptocarya & rigida \\
\hline Meliaceae & Dyoxylum & melleri \\
\hline Myrtaceae & Syzygium & crebrinerva \\
\hline Lauraceae & Endiandra & pubens \\
\hline Cunoniaceae & Caldcluvia & paniculosa \\
\hline Euphorbiaceae & Glochidion & ferdinandi \\
\hline Sapindaceae & Castanospora & alphandii \\
\hline Sapindaceae & Diploglottis & australis \\
\hline Myrtaceae & Austromyrtus & lasioclada \\
\hline Moraceae & Ficus & watkinsiana \\
\hline Lauraceae & Neolitsea & dealbata \\
\hline Icacinaceae & Pennantia & cunninghamii \\
\hline Myrtaceae & Lophostemon & confertus \\
\hline Cunoniaceae & Geissois & benthamii \\
\hline Meliaceae & Synoum & glandulosum \\
\hline Euphorbiaceae & Malotus & philippensis \\
\hline Icacinaceae & Citronella & moorei \\
\hline Myrtaceae & Acema & smithii var. minor \\
\hline Myrtaceae & Syzygium & australe \\
\hline Myrtaceae & Syzygium & hodgkinsoniae \\
\hline Myrtaceae & Tristaniosis & laurina \\
\hline Lauraceae & Cryptocarya & obovata \\
\hline Urticaceae & Dendrocnide & excelsa \\
\hline Urticaceae & Dendrocnide & photinophylla \\
\hline Eupomatiaceae & Eupomatia & laurina \\
\hline Lauraceae & Cryptocarya & glaucescens \\
\hline Lauraceae & Endiandra & muelleri \\
\hline Pittosporaceae & Hymenosporum & fiavum \\
\hline Pittosporaceae & Pittosporum & undulatum \\
\hline Cunoniaceae & Ceratopetalum & apetalum \\
\hline Cunoniaceae & Schizomeria & ovata \\
\hline Mimosaceae & Acacia & melanoxylon \\
\hline
\end{tabular}

\begin{tabular}{|c|c|c|c|c|c|}
\hline & & Site & & & Max of \\
\hline Common & 1 & 2 & 3 & $\begin{array}{l}\text { abund. } \\
\text { ratings }\end{array}$ & $\begin{array}{l}\text { abund. } \\
\text { ratings }\end{array}$ \\
\hline Bangalow palm & 10 & 10 & 10 & 10.0 & 10 \\
\hline Mainden's blush & 10 & 10 & 3 & 7.7 & 10 \\
\hline Blue fig & 3 & 6 & 10 & 6.3 & 10 \\
\hline Elderberry & 3 & 3 & 10 & 5.3 & 10 \\
\hline Red cedar & 10 & & 6 & 5.3 & 10 \\
\hline Creek sandpaper fig & 6 & 6 & 3 & 5.0 & 6 \\
\hline Socketwood & 6 & 3 & 1 & 3.3 & 6 \\
\hline Rose maple & & & 10 & 3.3 & 10 \\
\hline Red bean & 10 & & & 3.3 & 10 \\
\hline Purple cherry & 10 & & & 3.3 & 10 \\
\hline White bark walnut & 6 & 3 & & 3.0 & 6 \\
\hline Corkwood & 3 & & 6 & 3.0 & 6 \\
\hline Cheese tree & 6 & & 3 & 3.0 & 6 \\
\hline Brown tamarind & 6 & 3 & & 3.0 & 6 \\
\hline Tamarind & 6 & & 3 & 3.0 & 6 \\
\hline Velvet myrtle & 6 & 3 & & 3.0 & 6 \\
\hline Strangler fig & 1 & & 6 & 2.3 & 6 \\
\hline White bolly gum & 1 & & 6 & 2.3 & 6 \\
\hline Brown beech & 3 & 1 & 3 & 2.3 & 3 \\
\hline Brush box & 1 & & 6 & 2.3 & 6 \\
\hline Red carabeen & 6 & & & 2.0 & 6 \\
\hline Scentless rosewood & & & 6 & 2.0 & 6 \\
\hline Orange kamalla & 3 & & 3 & 2.0 & 3 \\
\hline Soapy box & 3 & & 3 & 2.0 & 3 \\
\hline Small leaved lilly pilly & 6 & & & 2.0 & 6 \\
\hline Brush cherry & & & 6 & 2.0 & 6 \\
\hline Smooth-bark rose apple & 6 & & & 2.0 & 6 \\
\hline Water gum & 6 & & & 2.0 & 6 \\
\hline Pepperberry & 3 & 1 & 1 & 1.7 & 3 \\
\hline Giant stinging tree & 1 & & 3 & 1.3 & 3 \\
\hline Shining-leaved stinging tree & 1 & & 3 & 1.3 & 3 \\
\hline Bolwarra & 1 & & 3 & 1.3 & 3 \\
\hline Jackwood & 1 & & 3 & 1.3 & 3 \\
\hline Green-leaved rose walnut & 3 & & 1 & 1.3 & 3 \\
\hline Native frangipani & 1 & & 3 & 1.3 & 3 \\
\hline Sweet pittosporum & 3 & & 1 & 1.3 & 3 \\
\hline Coachwood & 1 & & 3 & 1.3 & 3 \\
\hline Crabapple & 1 & & 3 & 1.3 & 3 \\
\hline Blackwood & 1 & & 3 & 1.3 & 3 \\
\hline
\end{tabular}




\begin{tabular}{|c|c|c|c|c|c|c|}
\hline Meliaceae & Melia & azedarach var. australasica & White cedar & 1 & 3 & 1.3 \\
\hline Anacardiaceae & Euroschinus & falcata & Chinaman's cedar & 3 & 1 & 1.3 \\
\hline Sapindaceae & Guioa & semiglauca & Guioa & 1 & 3 & 1.3 \\
\hline Myrtaceae & Syzygium & olersum & Blue cherry & 1 & 3 & 1.3 \\
\hline
\end{tabular}

Suballiance No. 5 Castanospermum - Dysoxylum mollissimum

Site
1
2
3
4

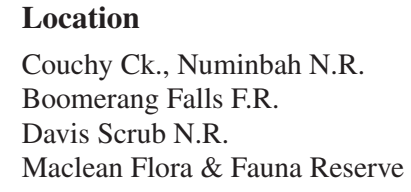

\begin{tabular}{|c|c|c|c|c|c|c|c|c|c|}
\hline \multirow[b]{2}{*}{ Family } & \multirow[b]{2}{*}{ Genus } & \multirow[b]{2}{*}{ Species } & \multirow[b]{2}{*}{ Common } & \multicolumn{4}{|c|}{ Site } & \multirow{2}{*}{$\begin{array}{c}\text { Av. } \\
\text { abund. } \\
\text { ratings }\end{array}$} & \multirow{2}{*}{$\begin{array}{l}\text { Max of } \\
\text { abund. } \\
\text { ratings }\end{array}$} \\
\hline & & & & 1 & 2 & 3 & 4 & & \\
\hline Fabaceae & Castanospermum & australe & Black bean & 10 & 10 & 10 & 10 & 10.0 & 10 \\
\hline Meliaceae & Dyoxylum & muelleri & Red bean & & & 10 & 10 & 5.0 & 10 \\
\hline Cunoniaceae & Geissois & benthamii & Red carabeen & 3 & 10 & & & 3.3 & 10 \\
\hline Elaeocarpaceae & Sloanea & australis & Mainden's blush & & 10 & 3 & & 3.3 & 10 \\
\hline Meliaceae & Anthocarapa & nitidula & Bog onion & 3 & 6 & 3 & & 3.0 & 6 \\
\hline Lauraceae & Cryptocarya & obovata & Pepperberry & 1 & 3 & 1 & 6 & 2.8 & 6 \\
\hline Moraceae & Ficus & watkinsiana & Strangler fig & 6 & 3 & & 1 & 2.5 & 6 \\
\hline Mimosaceae & Pararchidendron & pruinosum & Snow-wood & 3 & 1 & 3 & 3 & 2.5 & 3 \\
\hline Sapindaceae & Diploglottis & australis & Tamarind & 1 & 3 & 3 & 3 & 2.5 & 3 \\
\hline Moraceae & Ficus & fraseri & Sandpaper fig & & & 6 & 3 & 2.3 & 6 \\
\hline Urticaceae & Dendrocnide & photinophylla & Shining-leaved stinging tree & 6 & & & 3 & 2.3 & 6 \\
\hline Lauraceae & Endiandra & muelleri & Green-leaved rose walnut & & 3 & 6 & & 2.3 & 6 \\
\hline Lauraceae & Endiandra & pubens & White bark walnut & 3 & & 6 & & 2.3 & 6 \\
\hline Rutaceae & Flindersia & schottina & Bumpy ash & & & 6 & 3 & 2.3 & 6 \\
\hline Meliaceae & Toona & australis & Red cedar & 3 & & 3 & 3 & 2.3 & 3 \\
\hline Sapindaceae & Arytera & distylis & Two-leaved coogara & 6 & & 3 & & 2.3 & 6 \\
\hline Sapindaceae & Jagera & pseudohus & Foambark & 3 & & 3 & 3 & 2.3 & 3 \\
\hline Elaeocarpaceae & Sloanea & woollsii & Yellow carabeen & & 6 & 3 & & 2.3 & 6 \\
\hline Sterculiaceae & Argyrodendron & trifoliolatum & White booyong & 3 & 3 & 3 & & 2.3 & 3 \\
\hline Sterculiaceae & Brachychiton & acerifolius & Flame tree & 6 & 1 & 1 & & 2.0 & 6 \\
\hline Ulmaceae & Aphananthe & philippinensis & Native elm & & & 1 & 6 & 1.8 & 6 \\
\hline Urticaceae & Dendrocnide & excelsa & Giant stinging tree & 3 & & 3 & 1 & 1.8 & 3 \\
\hline Rutaceae & Sarcomelicope & simplicifolia & Yellow acronychia & & 1 & 3 & 3 & 1.8 & 3 \\
\hline Meliaceae & Melia & azedarach var australasica & White cedar & 3 & & 3 & 1 & 1.8 & 3 \\
\hline Sapindaceae & Sarcopteryx & stipata & Steelwood & 6 & & 1 & & 1.8 & 6 \\
\hline Rhamnaceae & Alphitonia & excelsa & Red ash & 3 & & 3 & 1 & 1.8 & 3 \\
\hline Myrtaceae & Lophostemon & confertus & Brush box & 6 & & & 1 & 1.8 & 6 \\
\hline Myrtaceae & Syzygium & crebrinerva & Purple cherry & & 1 & 6 & & 1.8 & 6 \\
\hline Myrtaceae & Syzygium & hodgkinsoniae & Smooth-bark rose apple & 6 & & 1 & & 1.8 & 6 \\
\hline Araliaceae & Polyscias & legans & Celery wood & 3 & & 3 & 1 & 1.8 & 3 \\
\hline Ebenaceae & Diospyros & pentamera & Grey persimmon & 3 & 1 & 3 & & 1.8 & 3 \\
\hline Moraceae & Streblus & brunonianus & Whalebone tree & & & & 6 & 1.5 & 6 \\
\hline Proteaceae & Macadamia & tetraphylla & Rough-shelled bush nut & & & 3 & 3 & 1.5 & 3 \\
\hline Atherospermataceae & Daphnandra & tenuipes & Red-flowered socketwood & 3 & 3 & & & 1.5 & 3 \\
\hline Lauraceae & Neolitsea & australiensis & Smooth-barked booly gum & & & 6 & & 1.5 & 6 \\
\hline Lauraceae & Neolitsea & dealbata & White bolly gum & 3 & & 3 & & 1.5 & 3 \\
\hline Cunoniaceae & Pseudoweinmannia & lachnocarpa & Mararie & 6 & & & & 1.5 & 6 \\
\hline Rutaceae & Euodia & micrococca & White euodia & & & 6 & & 1.5 & 6 \\
\hline Rutaceae & Melicope & octandra & Doughwood & & & 6 & & 1.5 & 6 \\
\hline Meliaceae & Dyoxylum & fraserianum & Rosewood & 3 & & 3 & & 1.5 & 3 \\
\hline Euphorbiaceae & Actephila & lindleyi & Actephila & & & 6 & & 1.5 & 6 \\
\hline Euphorbiaceae & Malotus & discolor & Yellow kamalla & & & 6 & & 1.5 & 6 \\
\hline Euphorbiaceae & Malotus & philippensis & Orange kamalla & & & 3 & 3 & 1.5 & 3 \\
\hline
\end{tabular}




\section{Suballiance No. 6 Archontophoenix - Livistona}

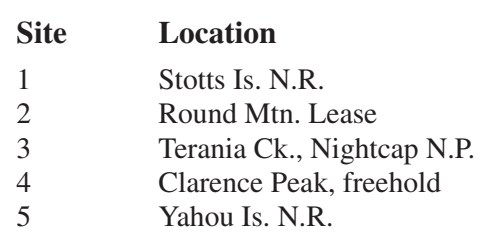

\begin{tabular}{|c|c|c|c|c|c|c|c|c|c|c|}
\hline \multirow[b]{2}{*}{ Family } & \multirow[b]{2}{*}{ Genus } & \multirow[b]{2}{*}{ Species } & \multirow[b]{2}{*}{ Common } & \multicolumn{5}{|c|}{ Site } & \multirow{2}{*}{$\begin{array}{c}\text { Av. } \\
\text { abund. } \\
\text { ratings }\end{array}$} & \multirow{2}{*}{$\begin{array}{l}\text { Max of } \\
\text { abund. } \\
\text { ratings }\end{array}$} \\
\hline & & & & 1 & 2 & 3 & 4 & 5 & & \\
\hline Arecaceae & Archontophoenix & cunninghamiana & Bangalow palm & 3 & 10 & 10 & 10 & & 6.6 & 10 \\
\hline Arecaceae & Livistona & australis & Cabbage tree palm & 10 & 3 & & 10 & 10 & 6.6 & 10 \\
\hline Elaeocarpaceae & Sloanea & australis & Mainden's blush & & 3 & 10 & & & 2.6 & 10 \\
\hline Epacridaceae & Trochocarpa & laurina & Tree heath & & 3 & & 10 & & 2.6 & 10 \\
\hline Moraceae & Ficus & coronata & Creek sandpaper fig & & 6 & 6 & & & 2.4 & 6 \\
\hline Lauraceae & Endiandra & discolor & Rose walnut & & 6 & & 6 & & 2.4 & 6 \\
\hline Elaeocarpaceae & Elaeocarpus & grandis & Blue fig & & 6 & 6 & & & 2.4 & 6 \\
\hline Sapotaceae & Planchonella & laurifolia & Blush coondoo & & 10 & & & & 2 & 10 \\
\hline Meliaceae & Synoum & glandulosum & Scentless rosewood & & 3 & & 6 & & 1.8 & 6 \\
\hline Euphorbiaceae & Glochidion & ferdinandi & Cheese tree & & & & 3 & 6 & 1.8 & 6 \\
\hline Myrtaceae & Melaleuca & quinquenervia & Broad-leaved paper-bark & 3 & & & & 6 & 1.8 & 6 \\
\hline Oleraceae & Notelaea & lonifolia & Large mock-olive & & 3 & & & 6 & 1.8 & 6 \\
\hline Elaeocarpaceae & Elaeocarpus & obovatus & Blueberry ash & 6 & 1 & 1 & & & 1.6 & 6 \\
\hline Rutaceae & Acronychia & oblongifolia & Common acronychia & & & & 1 & 6 & 1.4 & 6 \\
\hline Casuarinaceae & Casuarina & glauca & Swamp she-oak & 3 & & & & 3 & 1.2 & 3 \\
\hline Lauraceae & Endiandra & globosa & Black walnut & & 6 & & & & 1.2 & 6 \\
\hline Lauraceae & Neolitsea & dealbata & White bolly gum & & 6 & & & & 1.2 & 6 \\
\hline Cunoniaceae & Ceratopetalum & gummiferum & NSW christmas bush & & & & 6 & & 1.2 & 6 \\
\hline Cunoniaceae & Schizomeria & ovata & Crabapple & & & & 6 & & 1.2 & 6 \\
\hline Mimosaceae & Acacia & maidenii & Mainden's wattle & & & & & 6 & 1.2 & 6 \\
\hline Mimosaceae & Archidendron & grandifolorum & Pink lace-flower & & 3 & 3 & & & 1.2 & 3 \\
\hline Euphorbiaceae & Glochidion & sumatranum & Umbrella cheese tree & & 6 & & & & 1.2 & 6 \\
\hline Myrtaceae & Acema & smithii & Lilli Pilly & & & & 3 & 3 & 1.2 & 3 \\
\hline Myrtaceae & Callistemon & salignus & White bottlebrush & & & & & 6 & 1.2 & 6 \\
\hline Myrtaceae & Rhodamnia & maideniana & Smooth-leaved brush turpentine & & 6 & & & & 1.2 & 6 \\
\hline Myrtaceae & Syzygium & olersum & Blue cherry & & 3 & & 3 & & 1.2 & 3 \\
\hline Rubiaceae & Hodgkinsonia & ovatiflora & Golden ash & & 3 & & 3 & & 1.2 & 3 \\
\hline Lauraceae & Cryptocarya & obovata & Pepperberry & 1 & 3 & 1 & & & 1 & 3 \\
\hline Meliaceae & Dyoxylum & melleri & Red bean & 1 & 3 & & & & 0.8 & 3 \\
\hline Sapindaceae & Mischocarpus & pyiformis & Brush apple & 1 & 3 & & & & 0.8 & 3 \\
\hline Myrtaceae & Syzygium & moorei & Rose apple & 1 & 3 & & & & 0.8 & 3 \\
\hline Araucariaceae & Araucaria & cunninghamii & Hoop pine & 3 & & & & & 0.6 & 3 \\
\hline Moraceae & Ficus & fraseri & Sandpaper fig & & & & & 3 & 0.6 & 3 \\
\hline Moraceae & Ficus & watkinsiana & Strangler fig & & 3 & & & & 0.6 & 3 \\
\hline Atherospermataceae & Daphnandra & micrantha & Socketwood & & & 3 & & & 0.6 & 3 \\
\hline Lauraceae & Cryptocarya & glaucescens & Jackwood & & & & 3 & & 0.6 & 3 \\
\hline Lauraceae & Cryptocarya & rigida & Rose maple & & & & 3 & & 0.6 & 3 \\
\hline Lauraceae & Endiandra & muelleri & Green-leaved rose walnut & & 3 & & & & 0.6 & 3 \\
\hline Lauraceae & Endiandra & pubens & White bark walnut & & & 3 & & & 0.6 & 3 \\
\hline Lauraceae & Endiandra & sieberi & Hard corkwood & & & & 3 & & 0.6 & 3 \\
\hline Escelloniaceae & Cuttsia & viburnea & Elderberry & & & 3 & & & 0.6 & 3 \\
\hline Pittosporaceae & Hymenosporum & fiavum & Native frangipani & & 3 & & & & 0.6 & 3 \\
\hline Pittosporaceae & Pittosporum & undulatum & Sweet pittosporum & & & & 3 & & 0.6 & 3 \\
\hline
\end{tabular}




\section{Suballiance No. 16 Syzygium luehmannii - Acmena hemilampra}

$\begin{array}{ll}\text { Site } & \text { Location } \\ 1 & \text { Broken Head N.R. \& Rec. Reserve } \\ 2 & \text { luka N.R. } \\ 3 & \text { Bundagen F.R. } \\ 4 & \text { Yarrahapinni Ecology Study Centre }\end{array}$

\begin{tabular}{|c|c|c|c|c|c|c|c|c|c|}
\hline Family & Genus & Species & Common & 1 & 2 & 3 & 4 & $\begin{array}{l}\text { abund. } \\
\text { ratings }\end{array}$ & $\begin{array}{l}\text { abund. } \\
\text { ratings }\end{array}$ \\
\hline Sapindaceae & Mischocarpus & pyiformis & Brush apple & 6 & 10 & 6 & 10 & 8.0 & 10 \\
\hline Myrtaceae & Syzygium & luehmannii & Riberry & & 10 & 10 & 10 & 7.5 & 10 \\
\hline Sapindaceae & Cupaniopsis & anacardioides & Tuckeroo & 10 & 6 & 10 & 3 & 7.3 & 10 \\
\hline Euphorbiaceae & Drypetes & australasica & Yellow tulip & 3 & 10 & 1 & 6 & 5.0 & 10 \\
\hline Rutaceae & Acronychia & imperforata & Beach acronychia & 3 & 10 & 3 & 3 & 4.8 & 10 \\
\hline Rutaceae & Flindersia & schottina & Bumpy ash & 3 & 10 & & 6 & 4.8 & 10 \\
\hline Anacardiaceae & Euroschinus & falcata & Chinaman's cedar & & 6 & 10 & 3 & 4.8 & 10 \\
\hline Moraceae & Ficus & watkinsiana & Strangler fig & & 6 & 6 & 6 & 4.5 & 6 \\
\hline Urticaceae & Dendrocnide & photinophylla & Shining-leaved stinging tree & & 6 & 6 & 6 & 4.5 & 6 \\
\hline Sapindaceae & Guioa & semiglauca & Guioa & 3 & 6 & 6 & 3 & 4.5 & 6 \\
\hline Arecaceae & Archontophoenix & cunninghamiana & Bangalow palm & 10 & 1 & 3 & 3 & 4.3 & 10 \\
\hline Rubiaceae & Hodgkinsonia & ovatiflora & Golden ash & 10 & 1 & 3 & 3 & 4.3 & 10 \\
\hline Podocacarpaceae & Podocarpus & elatus & Brown pine & 1 & 3 & 6 & 6 & 4.0 & 6 \\
\hline Ulmaceae & Aphananthe & philippinensis & Native elm & 10 & & & 6 & 4.0 & 10 \\
\hline Proteaceae & Banksia & integrifolia & Coast banksia & 3 & 3 & 10 & & 4.0 & 10 \\
\hline Celastraceae & Cassine & australis & Red olive berry & 3 & 6 & 6 & 1 & 4.0 & 6 \\
\hline Sapindaceae & Arytera & divaricara & Coogara & & 10 & 3 & 3 & 4.0 & 10 \\
\hline Myrtaceae & Acema & hemilampra & Broad-leaved lilly pilly & 6 & 10 & & & 4.0 & 10 \\
\hline Rubiaceae & Canthium & coprosmoides & Coast canthium & 6 & 6 & 1 & 3 & 4.0 & 6 \\
\hline Myrtaceae & Rhodomyrtus & psidioides & Native guava & 3 & 3 & 3 & 6 & 3.8 & 6 \\
\hline Myrtaceae & Syzygium & olersum & Blue cherry & 3 & 6 & 3 & 3 & 3.8 & 6 \\
\hline Oleraceae & Notelaea & lonifolia & Large mock-olive & & 6 & 3 & 6 & 3.8 & 6 \\
\hline Ebenaceae & Diospyros & pentamera & Grey persimon & & 10 & 3 & 1 & 3.5 & 10 \\
\hline Euphorbiaceae & Glochidion & ferdinandi & Cheese tree & 6 & 3 & 1 & 3 & 3.3 & 6 \\
\hline Lauraceae & Litsea & australis & Brown bolly gum & 3 & 3 & 3 & 3 & 3.0 & 3 \\
\hline Rutaceae & Flindersia & bennettiana & Bennett's ash & 6 & 6 & & & 3.0 & 6 \\
\hline Rutaceae & Halfordia & kendack & Saffronheart & 6 & 6 & & & 3.0 & 6 \\
\hline Sapindaceae & Alectryon & coniaceus & Beach bird's eye & & 6 & 6 & & 3.0 & 6 \\
\hline Myrtaceae & Lophostemon & confertus & Brush box & 3 & 3 & 3 & 3 & 3.0 & 3 \\
\hline Moraceae & Ficus & coronata & Creek sandpaper fig & & 1 & 3 & 6 & 2.5 & 6 \\
\hline Moraceae & Ficus & fraseri & Sandpaper fig & 3 & 3 & 1 & 3 & 2.5 & 3 \\
\hline Myrtaceae & Rhodamnia & argentea & Malletwood & & 6 & & 3 & 2.3 & 6 \\
\hline Epacridaceae & Trochocarpa & laurina & Tree heath & & 3 & 3 & 3 & 2.3 & 3 \\
\hline Myrtaceae & Acema & smithii & Lilli Pilly & & 1 & 6 & 1 & 2.0 & 6 \\
\hline Araliaceae & Polyscias & legans & Celery wood & 3 & 1 & 3 & 1 & 2.0 & 3 \\
\hline Ulmaceae & Celtis & paniculata & Native hackberry & & 3 & 1 & 3 & 1.8 & 3 \\
\hline Moraceae & Ficus & obliqua & Small-leaved fig & & 3 & 3 & 1 & 1.8 & 3 \\
\hline Lauraceae & Endiandra & discolor & Rose walnut & & 1 & 6 & & 1.8 & 6 \\
\hline Euphorbiaceae & Claoxylon & australe & Brittlewood & & 6 & 1 & & 1.8 & 6 \\
\hline Myrtaceae & Syzygium & australe & Brush cherry & 1 & & 6 & & 1.8 & 6 \\
\hline Araucariaceae & Araucaria & cunninghamii & Hoop pine & 6 & & & & 1.5 & 6 \\
\hline Arecaceae & Livistona & australis & Cabbage tree palm & & 3 & & 3 & 1.5 & 3 \\
\hline Lauraceae & Cryptocarya & triplinervis & Three veined laurel & 3 & 3 & & & 1.5 & 3 \\
\hline
\end{tabular}




\section{Suballiance No. 24 Castanospermum - Grevillea robusta}

Site

$\begin{array}{ll}1 & \text { Sawpit Ck., Border Ranges N.P. } \\ 2 & \text { Moore Park Rec. Reserve }\end{array}$

3 Yorklea, Freehold

\section{Family}

Fabaceae

Casuarinaceae

Ulmaceae

Euphorbiaceae

Moraceae

Proteaceae

Euphorbiaceae

Myrtaceae

Myrtaceae

Podocacarpaceae

Moraceae

Myrtaceae

Myrtaceae

Atherospermataceae

Mimosaceae

Surianaceae

Sapindaceae

Lauraceae

Lauraceae

Lauraceae

Meliaceae

Urticaceae

Lauraceae

Mimosaceae

Meliaceae

Meliaceae

Sapindaceae

Sterculiaceae

Sterculiaceae

Myrtaceae

Myrtaceae

Moraceae

Rutaceae

Sapindaceae

Sapindaceae

Sapindaceae

Ulmaceae

Urticaceae

Lauraceae

Lauraceae

Lauraceae

Lauraceae

Pittosporaceae

\section{Genus}

Castanospermum

Casuarina

Aphananthe

Baloghia

Ficus

Grevillea

Malotus

Syzygium

Syzygium

Podocarpus

Streblus

Eucalyptus

Melaleuca

Daphnandra

Acacia

Guifoylia

Arytera

Beilschmiedia

Cryptocarya

Cryptocarya

Toona

Dendrocnide

Beilschmiedia

Pararchidendron

Dyoxylum

Melia

Elattostachys

Argyrodendron

Argyrodendron

Acema

Callistemon

Ficus

Acronychia

Alectryon

Diploglottis

Guioa

Celtis

Dendrocnide

Endiandra

Litsea

Neolitsea

Neolitsea

Hymenosporum
Species

australe

cunninghamiana

philippinensis

inophylla

coronata

robusta

philippensis

australe

francisii

elatus

brunonianus

grandis

bracteata

micrantha

concurrens

monostylis

divaricara

elliptica

obovata

triplinervis

australis

excelsa

obtusifolia

pruinosum

fraserianum

azedarach var. australasica White cedar

nervosa

actinophyllum

trifoliolatum

smithii

viminalis

macrophylla

oblongifolia

subcinereus

australis

semiglauca

paniculata

photinophylla

muelleri

australis

australiensis

dealbata

fiavum
Common

Black bean

River oak

Native elm

Brush bloodwood

Creek sandpaper fig

Silky oak

Orange kamalla

Brush cherry

Giant water-gum

Brown pine

Whalebone tree

Flooded gum

White cloud tree

Socketwood

Curracabah

Native plum

Coogara

Grey walnut

Pepperberry

Three veined laurel

Red cedar

Giant stinging tree

Hard bolly gum

Snow-wood

Rosewood

Beetroot

Black booyong

White booyong

Lilli Pilly

Drooping bottlebrush

Moreton bay fig

Common acronychia

Wild quince

Tamarind

Guioa

Native hackberry

Shining-leaved stinging tree

Green-leaved rose walnut

Brown bolly gum

Smooth-barked booly gum

White bolly gum

Native frangipani

\begin{tabular}{|c|c|c|c|c|}
\hline \multicolumn{3}{|c|}{ Site } & \multirow{2}{*}{$\begin{array}{l}\text { Av. } \\
\text { abund. } \\
\text { ratings }\end{array}$} & \multirow{2}{*}{$\begin{array}{l}\text { Max of } \\
\text { abund. } \\
\text { ratings }\end{array}$} \\
\hline 1 & 2 & 3 & & \\
\hline \multirow[t]{2}{*}{6} & 10 & 10 & 8.7 & 10 \\
\hline & 10 & 6 & 5.3 & 10 \\
\hline 3 & 10 & 3 & 5.3 & 10 \\
\hline 6 & 10 & & 5.3 & 10 \\
\hline 6 & 6 & 3 & 5.0 & 6 \\
\hline 3 & 10 & 1 & 4.7 & 10 \\
\hline 3 & 6 & 3 & 4.0 & 6 \\
\hline 6 & 3 & 3 & 4.0 & 6 \\
\hline \multirow[t]{2}{*}{10} & 1 & & 3.7 & 10 \\
\hline & 10 & & 3.3 & 10 \\
\hline 3 & 6 & 1 & 3.3 & 6 \\
\hline \multirow[t]{2}{*}{10} & & & 3.3 & 10 \\
\hline & 10 & & 3.3 & 10 \\
\hline \multirow[t]{2}{*}{6} & 3 & & 3.0 & 6 \\
\hline & 6 & 3 & 3.0 & 6 \\
\hline 6 & 3 & & 3.0 & 6 \\
\hline 6 & 3 & & 3.0 & 6 \\
\hline 1 & 6 & & 2.3 & 6 \\
\hline \multirow[t]{2}{*}{3} & 3 & 1 & 2.3 & 3 \\
\hline & 1 & 6 & 2.3 & 6 \\
\hline 6 & 1 & & 2.3 & 6 \\
\hline 6 & & & 2.0 & 6 \\
\hline \multirow[t]{2}{*}{3} & 3 & & 2.0 & 3 \\
\hline & 6 & & 2.0 & 6 \\
\hline 6 & & & 2.0 & 6 \\
\hline 3 & 3 & & 2.0 & 3 \\
\hline 6 & & & 2.0 & 6 \\
\hline 6 & & & 2.0 & 6 \\
\hline \multirow[t]{3}{*}{6} & & & 2.0 & 6 \\
\hline & & 6 & 2.0 & 6 \\
\hline & 3 & 3 & 2.0 & 3 \\
\hline \multirow[t]{2}{*}{3} & 1 & & 1.3 & 3 \\
\hline & 1 & 3 & 1.3 & 3 \\
\hline 3 & 1 & & 1.3 & 3 \\
\hline 3 & 1 & & 1.3 & 3 \\
\hline \multirow[t]{2}{*}{3} & 1 & & 1.3 & 3 \\
\hline & 3 & & 1.0 & 3 \\
\hline 3 & & & 1.0 & 3 \\
\hline 1 & 1 & 1 & 1.0 & 1 \\
\hline 3 & & & 1.0 & 3 \\
\hline 3 & & & 1.0 & 3 \\
\hline & 3 & & 1.0 & 3 \\
\hline & 3 & & 1.0 & 3 \\
\hline
\end{tabular}




\section{Suballiance No. 33 Ceratopetalum/Schizomeria - Argyrodendron/Sloanea}

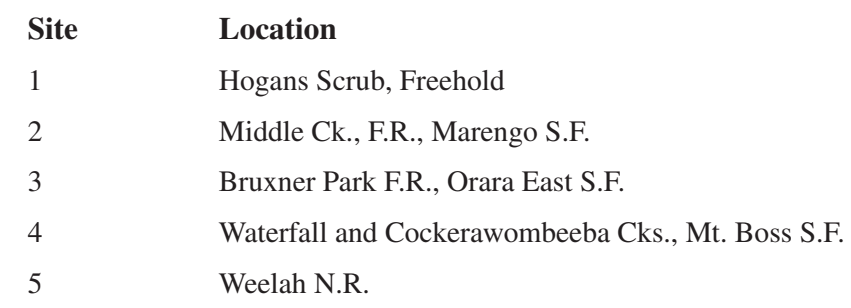

\begin{tabular}{|c|c|c|c|c|c|c|c|c|c|c|}
\hline \multirow[b]{2}{*}{ Family } & \multirow[b]{2}{*}{ Genus } & \multirow[b]{2}{*}{ Species } & \multirow[b]{2}{*}{ Common } & \multicolumn{5}{|c|}{ Site } & \multirow{2}{*}{$\begin{array}{c}\text { Av. } \\
\text { abund. } \\
\text { ratings }\end{array}$} & \multirow{2}{*}{$\begin{array}{l}\text { Max of } \\
\text { abund. } \\
\text { ratings }\end{array}$} \\
\hline & & & & 1 & 2 & 3 & 4 & 5 & & \\
\hline Elaeocarpaceae & Sloanea & woollsii & Yellow carabeen & 3 & 10 & 10 & 10 & 3 & 7.2 & 10 \\
\hline Cunoniaceae & Geissois & benthamii & Red carabeen & 1 & 3 & 6 & 10 & 6 & 5.2 & 10 \\
\hline Sterculiaceae & Argyrodendron & actinophyllum & Black booyong & & 10 & 3 & 6 & 6 & 5 & 10 \\
\hline Atherospermataceae & Doryphora & sassafras & Sassafras & 6 & 6 & 3 & 6 & 3 & 4.8 & 6 \\
\hline Cunoniaceae & Ceratopetalum & apetalum & Coachwood & 10 & 3 & 10 & & & 4.6 & 10 \\
\hline Arecaceae & Archontophoenix & cunninghamiana & Bangalow palm & 10 & & 10 & & & 4 & 10 \\
\hline Lauraceae & Cryptocarya & meissneriana & Thick-leaved laurel & 3 & & & 10 & 6 & 3.8 & 10 \\
\hline Escelloniaceae & Polyosma & cunninghamii & Featherwood & 3 & 3 & 6 & 3 & 3 & 3.6 & 6 \\
\hline Cunoniaceae & Caldcluvia & paniculosa & Corkwood & 3 & 3 & 3 & 3 & 6 & 3.6 & 6 \\
\hline Lauraceae & Cryptocarya & microneura & Murrogun & 3 & & 6 & 1 & 6 & 3.2 & 6 \\
\hline Elaeocarpaceae & Sloanea & australis & Mainden's blush & 6 & & 10 & & & 3.2 & 10 \\
\hline Moraceae & Ficus & coronata & Creek sandpaper fig & & 6 & 3 & 6 & & 3 & 6 \\
\hline Proteaceae & Orites & excelsa & Prickly ash & 3 & 6 & 3 & 3 & & 3 & 6 \\
\hline Cunoniaceae & Schizomeria & ovata & Crabapple & & 3 & 3 & 3 & 6 & 3 & 6 \\
\hline Meliaceae & Synoum & glandulosum & Scentless rosewood & 3 & & 3 & 3 & 6 & 3 & 6 \\
\hline Myrtaceae & Lophostemon & confertus & Brush box & 6 & & 6 & 3 & & 3 & 6 \\
\hline Ebenaceae & Diospyros & pentamera & Grey persimon & 3 & 3 & 6 & & 3 & 3 & 6 \\
\hline Moraceae & Ficus & watkinsiana & Strangler fig & 3 & & 10 & & 1 & 2.8 & 10 \\
\hline Lauraceae & Cryptocarya & glaucescens & Jackwood & 6 & 1 & 3 & 1 & 3 & 2.8 & 6 \\
\hline Epacridaceae & Trochocarpa & laurina & Tree heath & 3 & 1 & 3 & 1 & 6 & 2.8 & 6 \\
\hline Escelloniaceae & Quintinia & verdonii & Grey possumwood & 3 & & 6 & 1 & 3 & 2.6 & 6 \\
\hline Rutaceae & Acradenia & euodiiformia & Bonewood & & & 10 & 3 & & 2.6 & 10 \\
\hline Euphorbiaceae & Baloghia & inophylla & Brush bloodwood & & & & 3 & 10 & 2.6 & 10 \\
\hline Myrtaceae & Acema & smithii & Lilli Pilly & 6 & 1 & & 3 & 3 & 2.6 & 6 \\
\hline Atherospermataceae & Daphnandra & micrantha & Socketwood & & 1 & & 1 & 10 & 2.4 & 10 \\
\hline Lauraceae & Cryptocarya & rigida & Rose maple & & & 6 & 3 & 3 & 2.4 & 6 \\
\hline Icacinaceae & Pennan??a & cunninghamii & Brown beech & & 6 & & 3 & 3 & 2.4 & 6 \\
\hline Sapindaceae & Guioa & semiglauca & Guioa & 3 & & 3 & & 6 & 2.4 & 6 \\
\hline Rhamnaceae & Alphitonia & excelsa & Red ash & 6 & & 6 & & & 2.4 & 6 \\
\hline Myrtaceae & Rhodamnia & rubescens & Scub turpentine & 3 & & 6 & & 3 & 2.4 & 6 \\
\hline Lauraceae & Neolitsea & dealbata & White bolly gum & 3 & & 6 & 1 & 1 & 2.2 & 6 \\
\hline Sapindaceae & Diploglottis & australis & Tamarind & 3 & 1 & 3 & 1 & 3 & 2.2 & 3 \\
\hline Sapindaceae & Sarcopteryx & stipata & Steelwood & 3 & 1 & 3 & 1 & 3 & 2.2 & 3 \\
\hline Lauraceae & Endiandra & muelleri & Green-leaved rose walnut & 3 & & 3 & 1 & 3 & 2 & 3 \\
\hline Elaeocarpaceae & Elaeocarpus & reticulatus & Lily-of-the-valley tree & 3 & & 3 & 1 & 3 & 2 & 3 \\
\hline Lauraceae & Endiandra & discolor & Rose walnut & 6 & & 3 & & & 1.8 & 6 \\
\hline Myrtaceae & Eucalyptus & grandis & Flooded gum & 3 & & 6 & & & 1.8 & 6 \\
\hline Urticaceae & Dendrocnide & excelsa & Giant stinging tree & 1 & 1 & & 3 & 3 & 1.6 & 3 \\
\hline Proteaceae & Stenocarpus & salignus & Scrub beefwood & 1 & & 3 & 1 & 3 & 1.6 & 3 \\
\hline Meliaceae & Dyoxylum & fraserianum & Rosewood & 1 & 3 & & 1 & 3 & 1.6 & 3 \\
\hline Euphorbiaceae & Claoxylon & australe & Brittlewood & & 1 & 3 & 1 & 3 & 1.6 & 3 \\
\hline Sapotaceae & Planchonella & australis & Black apple & 3 & & 3 & 1 & 1 & 1.6 & 3 \\
\hline Verbenaceae & Gmelina & leichhardtii & White beech & 1 & & 3 & 1 & 3 & 1.6 & 3 \\
\hline
\end{tabular}




\section{Appendix 5. List of species from the brushes of the Richmond River region, as printed in the Clarence and Richmond Examiner and New England Advertiser, 1 April, 1873, p. 6.}

The likely current names were based on the original botanical name utilising the Australian Plant Census and Australian Plant Name Index.

Botanical name (1873)

Eucaliptus sideroploia

Eucaliptus rostrata

Eucaliptus saligna

Eucaliptus amygdalina

Eucaliptus robusta

Eucaliptus maculate

Eucaliptus corymbosa

Backhousia myrtifolia

Eugenia ventenatii

Eugenia jambolana

Eugenia myrtifolia

Eugenia sp.

Myrtus Becklerii

Myrtus Acmenioides

Rhodamnia trinervia

Callistemon salignus

Malaleuca styphellioides

Malaleuca leucadendron

Malaleuca armillaris

Tristania conferta

Tristania suavolens

Tristania neriifolia

Cedrela Australis

Flindersia Greaveaii

Flindersia Australis

Flindersia Oxleyana

Flindersia Schottiana

Flindersia Bennettiana

Dysoxylon Fraseranum

Dysoxylon Mullerii

Dysoxylon rufum

Melia composite

Acacia Cunninghamii

Acacia glaucescens

Castanospermum Australe

Castanospermum decurrens

Pithecolobium pruinosum

Monotoca elliptica

Echinocarpus Australis

El??ocarpus grandis

Sloanea Australis

Elcodendron Australe

Aracuaria Cunninghamii

Frenela columnaris

Grevillea robusta

Stenocarpus salignus

Stenocarpus sinuatus

Banksia serrata

Doryphora sassafras

Daphandra micrantha

Harpullia pendula

Diploglottis Cunninghamii

Cupania pseudorhus

Achras Australias

Ber?ali?ia sp.

Alphitonia excelsa

Cryptocarya glauceacens

Cryptocarya obvata

Tetranthera ferrugina

Weinmanni sp.

Grissois Benthemii
Local name

Ironbark

Flooded gum

Grey gum

Stringybark

Mahogany

Spotted gum

Bloodwood

Water gum

Durobby

Brush cherry

Coolmin

Myrtle

White myrtle

Three-veined myrtle

Broad-leaved tea tree

Fine-leaved tea tree

White tea tree

Small tea tree

Bastard box

Swamp mahogany

Water gum

Red cedar

Bulbura

Cudgery

Yellow wood

White wood

Bogum

Rosewood

Pencilwood

White cedar

Bastard myall

-

Beantree

Green wattle

A yellow wood

Sea coast box

-

Blue peach

Maiden's blush

Moreton Bay pine

Cypress pine

Silky oak

Beef wood

Honeysuckle

Sassafras

Light yellow wood

Tulip wood

Native tamarind

Light yellow wood

Black apple

Laurel

Sycamore

Murraree

\begin{tabular}{|c|c|c|}
\hline \multicolumn{2}{|c|}{ Height } & \multirow[t]{2}{*}{ Likely current botanical name } \\
\hline Feet & Metres & \\
\hline $100-50$ & $30-45$ & Eucalyptus siderophloia \\
\hline $100-50$ & $30-45$ & Eucalyptus camaldulensis \\
\hline $100-50$ & $30-45$ & Eucalyptus saligna \\
\hline $80-50$ & $24-45$ & Eucalyptus amygdalina \\
\hline $100-50$ & $30-45$ & Eucalyptus robusta \\
\hline 80-20 & $24-37$ & Corymbia maculata \\
\hline $70-20$ & $21-37$ & Corymbia gummifera \\
\hline 40 & 12 & Backhousia myrtifolia \\
\hline $70-90$ & $21-27$ & Syzygium floribundum \\
\hline $80-00$ & $24-30$ & Syzygium cumini \\
\hline $30-80$ & $9-24$ & Syzygium australe \\
\hline $100-50$ & $30-45$ & \\
\hline $60-80$ & $18-24$ & Archirhodomyrtus beckleri \\
\hline $60-80$ & $18-24$ & Gossia acmenoides \\
\hline $30-40$ & $9-12$ & Rhodamnia rubescens \\
\hline $60-80$ & $18-24$ & Callistemon salignus \\
\hline $30-40$ & $9-12$ & Melaleuca styphelioides \\
\hline $50-80$ & $15-24$ & Melaleuca leucadendra \\
\hline $20-30$ & $6-9$ & Melaleuса armillaris \\
\hline $80-30$ & $24-40$ & Lophostemon confertus \\
\hline $80-20$ & $24-37$ & Lophostemon suaveolens \\
\hline $80-00$ & $24-30$ & Tristania neriifolia \\
\hline $100-60$ & $30-49$ & Toona ciliata \\
\hline $100-60$ & $30-49$ & ?? \\
\hline $80-00$ & $24-30$ & Flindersia australis \\
\hline $80-00$ & $24-30$ & Flindersia xanthoxyla \\
\hline $80-00$ & $24-30$ & Flindersia schottiana \\
\hline $80-00$ & $24-30$ & Flindersia bennettiana \\
\hline $80-100$ & $24-30$ & Dysoxylum fraserianum \\
\hline $80-100$ & $24-30$ & Dysoxylum mollissimum \\
\hline $40-50$ & $12-15$ & Dysoxylum rufum \\
\hline $40-60$ & $12-18$ & Melia azedarach \\
\hline $30-40$ & $9-12$ & Acacia trinervata \\
\hline $50-70$ & $15-21$ & Acacia binervia \\
\hline $100-130$ & $30-40$ & Castanospermum australe \\
\hline $30-40$ & $9-12$ & ?? \\
\hline $30-50$ & $9-15$ & Pararchidendron pruinosum \\
\hline Handles & & Monotoca elliptica \\
\hline $100-150$ & $30-45$ & Sloanea australis \\
\hline $50-80$ & $15-24$ & Elaeocarpus grandis \\
\hline $30-40$ & $9-12$ & Sloanea Australis \\
\hline 30 & 9 & Elaeodendron australe \\
\hline $100-180$ & $30-55$ & Araucaria cunninghamii \\
\hline $50-80$ & $15-24$ & Callitris columellaris \\
\hline $60-80$ & $18-24$ & Grevillea robusta \\
\hline $60-80$ & $18-24$ & Stenocarpus salignus \\
\hline $80-100$ & $24-30$ & Stenocarpus sinuatus \\
\hline $30-50$ & $9-15$ & Banksia serrata \\
\hline $70-80$ & $21-24$ & Doryphora sassafras \\
\hline $70-90$ & $21-27$ & Daphnandra micrantha \\
\hline $30-40$ & $9-12$ & Harpullia pendula \\
\hline $60-90$ & $18-27$ & Diploglottis australis \\
\hline $50-80$ & $15-24$ & Jagera pseudorhus \\
\hline $60-100$ & $18-30$ & Planchonella australis \\
\hline $90-100$ & $27-30$ & \\
\hline $70-100$ & $21-30$ & Alphitonia excelsa \\
\hline $80-100$ & $24-30$ & Cryptocarya glaucescens \\
\hline 80-100 & $24-30$ & Cryptocarya obovata \\
\hline 80 & 24 & Litsea breviumbellata?? \\
\hline $100-150$ & $30-45$ & Pseudoweinmannia lachnoce \\
\hline $100-120$ & $30-37$ & Geissois benthamiana \\
\hline
\end{tabular}




\begin{abstract}
Avicennia tomentose Gmelina Leichardtii

Casaurina tennissima

Casaurina quadrivalvis

Baloghia lucida

Bradleia Australis

Cargillia pentamera

Celtis op?ca

Duboisra myoporoides

Memecyclon sp.

Myrsine varabilis

Pittisporum undulatum

Podocarpus spinulosus

Tarrietia actinodendron

Tarrietia argyrodendron

Tarrietia Carronii

Rhus rodanthema
\end{abstract}

$\begin{array}{lc}\text { Large mangrove } & 30-50 \\ \text { Beech } & 100-150 \\ \text { Forest oak } & 50-80 \\ \text { Swamp oak } & 40-90 \\ \text { Brush bloodwood } & 40 \\ \text { Red wood } & 50-70 \\ \text { Black myrtle } & 80-100 \\ - & 40-60 \\ \text { Cork wood } & 50 \\ \text { Brush cherry, cobbinmuni } & 60-80 \\ - & 20-50 \\ - & 30-40 \\ \text { Smooth bark pine } & 40-120 \\ \text { Stave wood } & 70-120 \\ \text { Iron wood } & 100-150 \\ \text { Byong } & 100-150 \\ \text { Dark yellow wood } & 50-80\end{array}$

$30-50$
$00-150$

50-80

$40-90$

50-70

$80-100$

-60

60-80

20-50

$70-120$

$0-150$

50-80

$\begin{array}{cl}9-15 & \text { Avicennia marina } \\ 30-45 & \text { Gmelina leichhardtii } \\ 15-24 & \text { Allocasuarina torulosa } \\ 12-27 & \text { Allocasuarina verticillata } \\ 12 & \text { Baloghia inophylla } \\ 15-21 & ? ? \\ 24-30 & \text { Diospyros pentamera } \\ 12-18 & ? ? \\ 15 & \text { Duboisia myoporoides } \\ 18-24 & \text { Memecylon sp. ?? } \\ 6-15 & \text { Myrsine variabilis } \\ 9-12 & \text { Pittosporum undulatum } \\ 12-37 & \text { Podocarpus spinulosus } \\ 21-37 & ? ? \\ 30-45 & ? ? \\ 30-45 & \text { Argyrodendron trifoliolatum ?? } \\ 15-24 & \text { Rhodosphaera rhodanthema }\end{array}$


